\title{
A fleet of multiparameter observatories for geophysical and environmental monitoring at seafloor
}

\author{
Paolo Favali $\left({ }^{1}\right)\left({ }^{2}\right)$, Laura Beranzoli $\left({ }^{1}\right)$, Giuseppe D’Anna $\left({ }^{1}\right)$, Francesco Gasparoni $\left(^{3}\right)$, \\ Jean Marvaldi $\left({ }^{4}\right)$, Günther Clauss $\left({ }^{5}\right)$, Hans W. Gerber $\left({ }^{6}\right)$, Michel Nicot $\left({ }^{7}\right)$, Michael P. Marani $\left({ }^{8}\right)$, \\ Fabiano Gamberi $\left({ }^{8}\right)$, Claude Millot $\left({ }^{9}\right)$ and Ernst R. Flueh $\left({ }^{10}\right)$ \\ (1) Istituto Nazionale di Geofisica e Vulcanologia, Roma, Italy \\ $\left({ }^{2}\right)$ Università degli Studi di Roma «La Sapienza», Roma, Italy \\ $\left(^{3}\right)$ Tecnomare-ENI SpA, Venezia, Italy \\ $\left(^{4}\right)$ IFREMER, Centre de Brest, Plouzané, France \\ $\left({ }^{5}\right)$ Technische Universität Berlin, Germany \\ $\left.{ }^{(}{ }^{6}\right)$ TFH Berlin - University of Applied Sciences, Berlin, Germany \\ $\left(^{7}\right)$ SERCEL-Underwater Acoustic Division (former ORCA Instrumentation), Brest, France \\ $\left.{ }^{8}\right)$ Istituto di Scienze Marine (ISMAR), CNR, Sezione di Geologia Marina, Bologna, Italy \\ $\left(^{9}\right)$ Laboratoire d'Océanographie et de Biogéochimie (LOB), La Seyne-sur-Mer, France \\ $\left({ }^{10}\right)$ IFM-GEOMAR, Kiel, Germany
}

\begin{abstract}
Seafloor long-term, multiparameter, single-frame observatories have been developed within the framework of European Commission and Italian projects since 1995. A fleet of five seafloor observatories, built-up starting from 1995 within the framework of an effective synergy among research institutes and industries, have carried out a series of long-term sea experiments. The observatories are able to operate from shallow waters to deep-sea, down to $4000 \mathrm{~m}$ w.d., and to simultaneously monitor a broad spectrum of geophysical and environmental processes, including seismicity, geomagnetic field variations, water temperature, pressure, salinity, chemistry, currents, and gas occurrence. Moreover, they can transmit data in (near)-real-time that can be integrated with those of the on-land networks. The architecture of the seafloor observatories follows the criteria of modularity, interoperability and standardisation in terms of materials, components and communication protocols. This paper describes the technical features of the observatories, their experiments and data.
\end{abstract}

Key words long-term multidisciplinary seafloor observatories - geophysical and environmental seabed monitoring

Mailing address: Dr. Paolo Favali, Istituto Nazionale di Geofisica e Vulcanologia, Via di Vigna Murata 605, 00143 Roma, Italy; e-mail: paolofa@ingv.it

\section{Introduction}

The European experience on seafloor monitoring started in early 1990s with the EC MAST (acronyms and abbreviations are listed before the references) Programme. Feasibility studies commissioned by the EC were addressed to identifying the scientific requirements (Thiel et al., 1994) and to establishing the possible technological solutions for the development of seafloor observatories (ABEL, Berta et al., 1995). In parallel, other studies and activities, such as DESIBEL (Ri- 
gaud et al., 1998), were carried out at EC level, aimed at defining needs and expectations for long-term investigations at abyssal depths. Meanwhile, the most technologically advanced countries have launched a large number of projects and programmes addressed to long-term and multiparameter seafloor monitoring. Favali and Beranzoli (2006) review these international efforts.

A widely accepted definition of seafloor observatories has progressively been affirmed at numerous international conferences and workshops (e.g., Chave et al., 1990; Montagner and
Lancelot, 1995; Utada et al., 1997; Romanowicz et al., 2001; Beranzoli et al., 2002; Kasahara and Chave, 2003). This definition outlined by NRC (2000) is:

« [...] unmanned system of instruments, sensors and command modules connected either acoustically or via seafloor junction box to a surface buoy or a cable to land. These observatories will have power and communication capabilities [...]».

Accordingly, a seafloor observatory is characterised by a data acquisition and control sys-

Table I. Requirements for the instrumentation used in seafloor observatories.

\begin{tabular}{|c|c|c|c|}
\hline Sensor & $\begin{array}{l}\text { Typical sampling } \\
\text { rates }\end{array}$ & $\begin{array}{l}\text { Data acquisition } \\
\text { (bits) }\end{array}$ & Installation constraints \\
\hline $\begin{array}{l}\text { Three-component } \\
\text { broad-band seismometer }\end{array}$ & $20 \div 100 \mathrm{~Hz}$ & 24 & $\begin{array}{l}\text { - Positioning (error } \leq 100 \mathrm{~m} \text { ). } \\
\text { - Orientation to the north }\left(\mathrm{known} \leq 1^{\circ} \text { ). }\right. \\
\text { - Good ground coupling. } \\
\text { - Fine levelling (if required). }\end{array}$ \\
\hline Hydrophone & $80 \div 100 \mathrm{~Hz}$ & 24 & - Positioning (error $\leq 100 \mathrm{~m}$ ). \\
\hline Gravity meter & $0.01 \div 1 \mathrm{~Hz}$ & 24 & $\begin{array}{l}\text { - Positioning. } \\
\text { - Temperature controlled. } \\
\text { - Fine levelling. }\end{array}$ \\
\hline Scalar magnetometer & $1 \mathrm{sample} / \mathrm{min}$ & 16 & $\begin{array}{l}\text { - Minimisation of possible electro-magnetic } \\
\text { interferences. }\end{array}$ \\
\hline Tri-axial fluxgate & $1 \mathrm{sample} / \mathrm{s}$ & 24 & $\begin{array}{l}\text { - Minimisation of possible electro-magnetic } \\
\text { interferences. }\end{array}$ \\
\hline Precision tilt meter $(X, Y)$ & $10 \mathrm{~Hz}$ & 24 & - Northwards orientation. \\
\hline $\begin{array}{l}\text { Tri-axial single-point } \\
\text { current meter }\end{array}$ & $2 \mathrm{~Hz}$ & 16 & - Avoiding frame interference. \\
\hline ADCP $300 \mathrm{kHz}$ & 1 profile/h & & - Avoiding frame interference. \\
\hline Transmissometer & 1 sample/h & & - Avoiding frame interference. \\
\hline CTD & $\begin{array}{l}1 \text { sample/10 min } \\
\text { (or } 1 \text { sample/h) }\end{array}$ & & \\
\hline $\mathrm{CH}_{4}$ sensor & $1 \mathrm{~Hz}$ & 24 & \\
\hline $\mathrm{H}_{2} \mathrm{~S}$ sensor & $\begin{array}{l}1 \text { sample/10 min } \\
\text { veraged on } 30 \text { samples/s) }\end{array}$ & 24 & \\
\hline$p H$ sensor & 1 sample/6 h $(*)$ & & $\begin{array}{l}\text { - Ampling and self-calibration programmable } \\
\text { - Self-calibration every } 24 \text { samples }(*) .\end{array}$ \\
\hline Water sampler & & & $\begin{array}{l}-48 \text { bottles, sampling depending on the } \\
\text { mission targets. }\end{array}$ \\
\hline
\end{tabular}

(*) ORION-GEOSTAR-3 configuration. 
tem, multiple sensors, long-term autonomy, communication systems, remote re-configuration of mission parameters, accurate positioning. Another important constraint to be considered is a unique time reference for all measurements, giving us the chance to compare different processes for exploring possible reciprocal relationships. The sensors themselves are suitable for long-term operation, when properly installed to provide highly reliable data. The requirements for the instrumentation, used in seafloor observatories, are shown in table I.

Between 1995 and 2001 the EC funded the GEOSTAR and GEOSTAR-2 projects (Beranzoli et al., 1998, 2000a,b; Favali et al., 2002) which designed, developed and operated a prototype autonomous deep-sea observatory (hereafter GEOSTAR) hosting a wide range of sensors in a single frame and providing facilities for external experiments. GEOSTAR satisfied the definition of seafloor observatory mentioned above with multidisciplinary, long-term monitoring capabilities providing time-referenced data series, and the chance to transmit data in (near)-real-time through a surface buoy. Moreover, the management of the observatory from the sea surface has represented an innovative approach exportable to other seafloor monitoring and survey applications. The GEOSTAR system has performed experiments both in shallow and deep waters, which confirmed the reliability and the feasibility of the deployment/recovery procedure even in a moderately perturbed sea state (Jourdain, 1999; Beranzoli et al., 2000a; Favali et al., 2002).

Two paths were followed after the GEOSTAR experience: the development of other single-frame observatories devoted to specific applications and the enhancement of GEOSTAR as principal node of a network of seafloor observatories. These paths have led to the current availability of four more GEOSTAR-class observatories and the first European prototype of a deep seafloor observatory network.

$\mathrm{SN}-1$ and GMM systems were developed (Favali et al., 2004a) among the single-frame GEOSTAR-class observatories. SN-1 is addressed to seismological, oceanographic and environmental measurements developed within a GNDT-funded project (Favali et al., 2003).
GMM, built within the EC ASSEM project (Blandin et al., 2003) is devoted to seafloor gas monitoring (Marinaro et al., 2004).

Within the framework of the EC ORIONGEOSTAR-3 project (Beranzoli et al., 2004), GEOSTAR was implemented to act as the main node of an underwater network of deep-sea observatories of GEOSTAR-class with the capability of (near)-real-time communication. In addition to this main node, two more observatories, with the function of satellite nodes (ORION Nodes 3 and 4), were built and equipped with seismological and oceanographic sensors.

The concomitant running of the ORIONGEOSTAR-3 and ASSEM projects has given us the chance to integrate one of the ORION nodes in the shallow water ASSEM system during the ASSEM pilot experiment in Corinth Gulf. This integration has been dedicated to demonstrating the compatibility of the two seafloor networks and the chance to operate a «coast-to-deep-sea» monitoring system in the near future.

This paper gives a technical description of the five above-mentioned seafloor observatories, together with the presentation of the acquired data. A sixth single-frame system, called MABEL, is being developed for polar sea applications within the framework of the Italian PNRA (Calcara et al., 2001). A short description of MABEL is also given.

\section{The GEOSTAR system}

GEOSTAR is a single-frame autonomous seafloor observatory, based on three main sub-systems (Beranzoli et al., 1998): a) the Bottom Station, that is the monitoring system; b) MODUS, the dedicated deployment/recovery vehicle; c) the Communication Systems. GEOSTAR is capable of long-term (more than one year) multidisciplinary monitoring at abyssal depths. At present, the maximum operative depth is $4000 \mathrm{~m}$.

\subsection{Bottom Station}

The Bottom Station (fig. 1) is a four-leg marine aluminium frame hosting the monitoring system including lithium batteries for power 


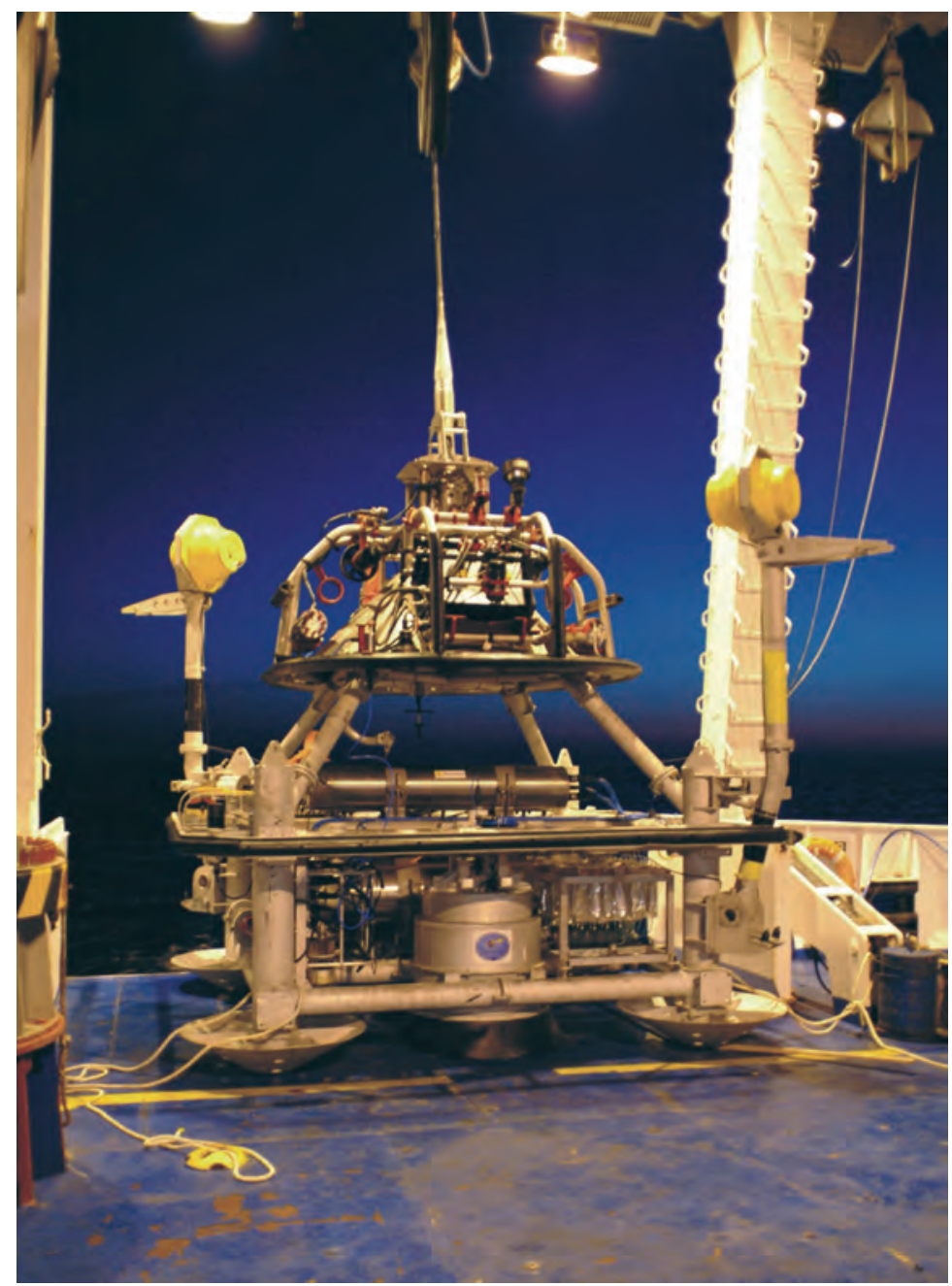

Fig. 1. GEOSTAR seafloor observatory: Bottom Station with MODUS vehicle on the top.

supply; electronics mounted inside titanium vessels; hard disks for data storage; the underwater part of the communication systems; scientific and status sensors.

The Bottom Station mission is driven and controlled by a central data acquisition and control unit (named DACS; Gasparoni et al., 2002). GEOSTAR DACS (fig. 2) can perform the following tasks: management and acquisition from all scientific packages and status sensors; preparation and continuous update of hourly data messages to be transmitted on request including detection of events; actuation of received commands (e.g., data request, system reconfiguration, re-start); data back-up on internal memory. DACS manages a wide set of data streams at quite different sampling rates (from $100 \mathrm{~Hz}$ to 1 sample/day) tagging each datum according to a unique reference time set by a central high-precision clock (stability within a 


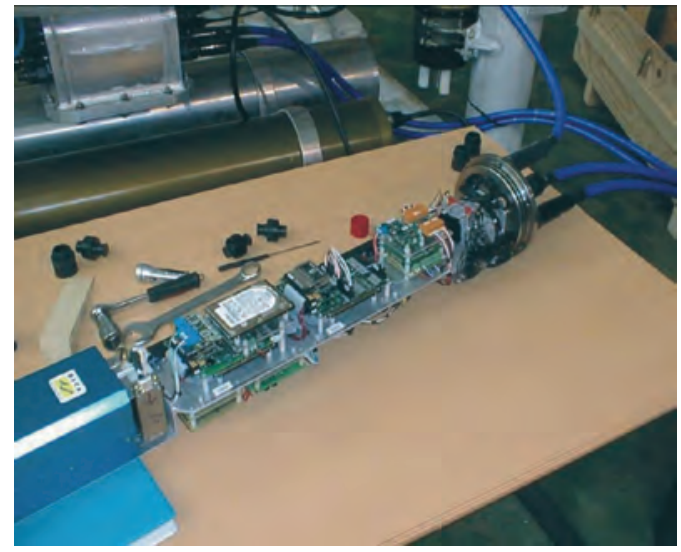

Fig. 2. DACS equipped with central Bottom Station high-precision clock (left-bottom) provided by SERCEL (former ORCA Instrumentation). range $10^{-9}$ to $10^{-11}$, accordingly to supplier specifications and verified during the experiments controlling the clock drift). The sensors were selected also in order to keep power consumption lower than $350 \mathrm{~mA}$ at $24 \mathrm{~V}$. Table II describes the GEOSTAR DACS' main technical characteristics. Devices were designed and implemented to install the seismometer and magnetometers with the aim of reducing the disturbances caused by the observatory frame and electronics. The former, installed in a benthosphere by the supplier, was included inside a heavy cylindrical housing. Then the whole package was released by a special device after the Bottom Station touch down to guarantee a good coupling with the sea bottom, and was kept linked to the Bottom Station frame by a

Table II. DACS main technical characteristics of the GEOSTAR-class platforms (e.g., Gasparoni et al., 2002).

\begin{tabular}{|c|c|c|c|c|c|c|}
\hline & GEOSTAR & SN-1 & $\begin{array}{l}\text { ORION } \\
\text { Node } 3\end{array}$ & $\begin{array}{l}\text { ORION } \\
\text { Node } 4\end{array}$ & GMM & $\operatorname{MABEL}\left({ }^{1}\right)$ \\
\hline Configuration & $\begin{array}{c}4 \mathrm{CPU} \\
\text { (MCU, SDU, } \\
\text { HDU, DAU) }\end{array}$ & $\begin{array}{c}3 \mathrm{CPU} \\
\text { (MCU, SDU, } \\
\text { HDU) }\end{array}$ & $\begin{array}{c}3 \text { CPU } \\
\text { (MCU, SDU, } \\
\text { HDU) }\end{array}$ & $\begin{array}{c}3 \text { CPU } \\
\text { (MCU, SDU, } \\
\text { HDU) }\end{array}$ & $1 \mathrm{CPU}$ & $\begin{array}{c}2 \mathrm{CPU} \\
\text { (MCU, SDU, }\end{array}$ \\
\hline \multirow[t]{3}{*}{ Mass memory } & $\begin{array}{c}3 \times 8 \mathrm{~Gb} \\
(2 \mathrm{HDs} \text { SDU, } \\
1 \text { HD HDU) }\end{array}$ & $\begin{array}{c}3 \times 8 \mathrm{~Gb} \\
(2 \mathrm{HDs} \text { SDU, } \\
1 \text { HD HDU) }\end{array}$ & $\begin{array}{c}3 \times 8 \mathrm{~Gb} \\
(2 \mathrm{HDs} \mathrm{SDU}, \\
1 \mathrm{HD} \mathrm{HDU})\end{array}$ & $\begin{array}{c}3 \times 8 \mathrm{~Gb} \\
(2 \mathrm{HDs} \mathrm{SDU}, \\
1 \mathrm{HD} \mathrm{HDU})\end{array}$ & $\begin{array}{l}512 \mathrm{Mb} \\
\text { (Flash) }\end{array}$ & $\begin{array}{c}30 \mathrm{~Gb} \\
\text { (HD SDU) }\end{array}$ \\
\hline & $\begin{array}{c}3 \times 64 \mathrm{Mb} \\
\text { (Flash MCU, } \\
\text { SDU, HDU) }\end{array}$ & $\begin{array}{c}1 \mathrm{~Gb} \\
\text { (Flash MCU) }\end{array}$ & $\begin{array}{c}3 \times 64 \mathrm{Mb} \\
\text { (Flash MCU, } \\
\text { SDU, HDU) }\end{array}$ & $\begin{array}{c}3 \times 64 \mathrm{Mb} \\
\text { (Flash MCU, } \\
\text { SDU, HDU) }\end{array}$ & & $\begin{array}{c}1 \mathrm{~Gb} \\
\text { (Flash MCU) }\end{array}$ \\
\hline & $\begin{array}{c}512 \mathrm{Mb} \\
\text { (Flash DAU) }\end{array}$ & $\begin{array}{c}2 \times 64 \mathrm{Mb} \\
\text { (Flash SDU, HDU } \\
\text { not used in RTL) }\end{array}$ & & & & $\begin{array}{c}128 \mathrm{Mb} \\
\text { (Flash SDU }\end{array}$ \\
\hline Power supply & $\begin{array}{l}24 \text { VDC } \\
\text { (battery) }\end{array}$ & $\begin{array}{c}12 \text { VDC } \\
\text { (battery or cable) }\end{array}$ & $\begin{array}{l}12 \text { VDC } \\
\text { (battery) }\end{array}$ & $\begin{array}{l}12 \text { VDC } \\
\text { (battery) }\end{array}$ & $\begin{array}{l}12 \mathrm{VDC} \\
\text { (battery) }\end{array}$ & $\begin{array}{l}12 \mathrm{VDC} \\
\text { (battery) }\end{array}$ \\
\hline $\begin{array}{c}\text { Power } \\
\text { consumption }\end{array}$ & $\begin{array}{c}70 \mathrm{~mA}(\mathrm{ID}) \\
300 \mathrm{~mA}(\mathrm{MM})\end{array}$ & $\begin{array}{c}200 \mathrm{~mA} \text { (ID) } \\
450 \mathrm{~mA}(\mathrm{MM})\end{array}$ & $\begin{array}{c}120 \mathrm{~mA}(\mathrm{ID}) \\
350 \mathrm{~mA}(\mathrm{MM})\end{array}$ & $\begin{array}{c}120 \mathrm{~mA}(\mathrm{ID}) \\
400 \mathrm{~mA}(\mathrm{MM})\end{array}$ & $\begin{array}{c}80 \mathrm{~mA}(\mathrm{ID}) \\
150 \mathrm{~mA}(\mathrm{MM}) \\
550 \mathrm{~mA} \text { (peak) }\end{array}$ & $\begin{aligned} & <80 \mathrm{~mA}(\mathrm{ID}) \\
< & 200 \mathrm{~mA}(\mathrm{MM})\end{aligned}$ \\
\hline $\begin{array}{l}\text { Communication } \\
\text { interfaces }\end{array}$ & $\begin{array}{l}\text { MODUS }\left({ }^{2}\right) \\
\text { V acoustics } \\
\text { H acoustics } \\
\text { MESSENGERS }\end{array}$ & $\begin{array}{l}\text { MODUS }\left(^{2}\right) \\
\text { V acoustics } \\
\text { Fibre-optic } \\
\text { telemetry }\end{array}$ & $\begin{array}{l}\text { MODUS }\left({ }^{2}\right) \\
\text { H acoustics }\end{array}$ & $\mathrm{H}$ acoustics & Cable telemetry & $\begin{array}{l}\text { MODUS }\left(^{2}\right) \\
\text { V acoustics }\end{array}$ \\
\hline
\end{tabular}

( $\left.{ }^{1}\right)$ The first polar experiment started at the end of 2005; $\left({ }^{2}\right)$ during deployment. MCU - Mission Control Unit; SDU - Seismometer Data acquisition Unit; HDU - Hydrophone Data acquisition Unit; DAU - Data Acquisition Unit; HD - Hard Disk; RTL - Real Time Link [mode]; ID - Idle mode: all sensors switched off; CPUs waiting command from the operator; MM - Mission Mode: all sensors switched on; CPUs and communications active; V - Vertical; $\mathrm{H}$ Horizontal. 
slack rope. Special care was taken in the choice of the electronic components of the INGV fluxgate magnetometer prototype. The resolution of this prototype is $1 \mathrm{nT}$ and an absolute accuracy $5 \mathrm{nT}$. The magnetometers, used in the early version, were scalar (Overhauser magnetometer) and bi-axial fluxgate (horizontal axes), then in all the subsequent experiments the INGV fluxgate prototype was fully tri-axial. They were installed at the end of two booms attached at opposite angles of the Bottom Station frame to keep them as far as possible from electronic noise sources. The booms, kept vertical during the descent, were opened by command from the surface through the umbilical cable, once the observatory was placed on the seafloor. The direction of the three components of the geomagnetic field was reconstructed using the scalar information (total field) deduced from the Overhauser magnetometer and from calibrating the fluxgate magnetometer in the air close to the Geomagnetic Observatory of L'Aquila (Central Italy). The results were also confirmed when compared with the horizontal component as deduced from a land magnetic station running during the first deep mission close to Ustica Island (Sicily, Italy) in 2000-2001 (see also De Santis et al., 2006).

\section{2. $M O D U S$}

MODUS, a simplified ROV, is the special vehicle for the deployment/recovery procedures (Clauss and Hoog, 2002; Clauss et al., 2004; Gerber and Clauss, 2005). MODUS is remotely controlled from the ship through a dedicated electro-opto-mechanical cable. The telemetry system also provides the primary communication link with the observatory during the deployment phase. It is equipped with a latch/release device and thrusters mounted on a frame around the cone that assists the docking. The aim is to load, deploy and recover the Bottom Station in surface-assisted mode. The MODUS frame is also equipped with video cameras for visual seabed inspection, compass, sonar and altimeter. The main MODUS characteristics are listed in table III, while the system is shown in fig. 3a-e including the latch/release scheme.
Table III. MODUS main characteristics (Clauss and Hoog, 2002; Clauss et al., 2004; Gerber and Clauss, 2005).

\begin{tabular}{cc}
\hline \hline Purpose & $\begin{array}{c}\text { Umbilical-driven } \\
\text { frequent operations }\end{array}$ \\
\hline Material & $\begin{array}{c}\text { Aluminium (frame) } \\
\text { Stainless steel } \\
\text { (docking device) } \\
\text { Titanium } \\
\text { (pressure vessels) }\end{array}$ \\
Weight in air $(\mathrm{kN})$ & 10 \\
Weight in water $(\mathrm{kN})$ & 7 \\
Total length- $L(\mathrm{~m})$ & 2878 \\
Total width- $W(\mathrm{~m})$ & 2348 \\
Total height- $H$ without cable & 1700 \\
termination $(\mathrm{m})$ & 30 \\
Maximum payload $(\mathrm{kN})$ & 25 \\
Power $(\mathrm{kW})$ & $4 \times 700$ \\
Horizontal thrusters $(\mathrm{N})$ & $2 \times 700$ \\
Vertical thrusters $(\mathrm{N})$ & 100 \\
Altimeter range $(\mathrm{m})$ & 1 \\
Heading accuracy $(\mathrm{degrees})$ & 1 \\
Tilt accuracy $($ degrees $)$ & 300 \\
$360^{\circ}$ sonar range $(\mathrm{m})$ & 6 \\
Video cameras $(+\mathrm{lights})$ & 4 \\
Videos and recorders & 4000 \\
Depth rated $(\mathrm{m})$ & \\
\hline
\end{tabular}

Table IV contains the main features of the handling system (winch, hydraulic unit and sheave) and cable (fig. 4).

\subsection{Communications systems}

Two independent Communication Systems were originally developed for GEOSTAR, based on different principles (Marvaldi et al., 2002). The first one consists of buoyant data capsules, named Messengers, releasable upon surface command or automatically, when full of data or in case of emergency. Two types of Messengers are available: a) expendable (data storage capacity $64 \mathrm{~Kb}$ ); b) storage (data storage capacity larger than the expandable, 40 $\mathrm{Mb}$ ). They can transmit their position at sea surface and small quantities of data via ARGOS satellites. The second communication system is based on a bi-directional vertical acoustic link 

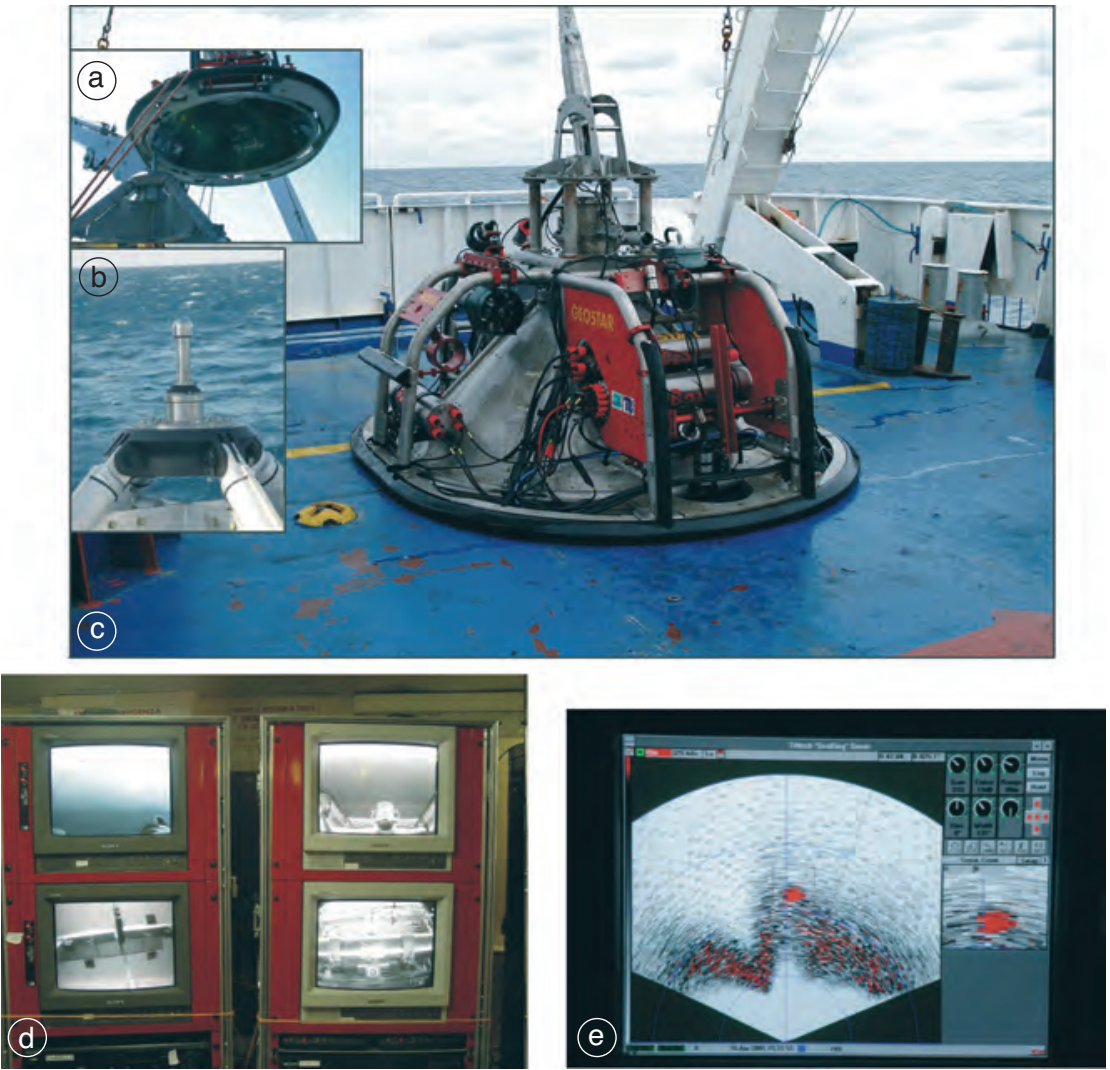

Fig. 3a-e. MODUS, the GEOSTAR deployment/recovery vehicle: a) docking cone and b) pin; c) MODUS on the deck of R/V Urania; d) MODUS on-board console; e) Bottom Station signature displayed on the sonar monitor.

Table IV. Main characteristics of the winch (MacArtney) and cable (Rochester).

\begin{tabular}{|c|c|c|c|c|c|c|}
\hline Item & Dimensions (m) & Weight $(\mathrm{kN})$ & $\begin{array}{l}\text { Max payout } \\
\text { speed (m/min) }\end{array}$ & Load $(\mathrm{kN})$ & Max pull $(\mathrm{kN})$ & Notes \\
\hline Winch & $\begin{array}{c}3.80 \times 2.35 \times 2.40 \\
(\mathrm{~L} \times \mathrm{W} \times \mathrm{H})\end{array}$ & 181 & $\begin{array}{l}70\left(^{\mathrm{a}}\right) \\
51\left(^{\mathrm{b}}\right)\end{array}$ & $80\left(^{(c)}\right.$ & $\begin{array}{l}102\left(^{(a)}\right. \\
75\left(^{b}\right)\end{array}$ & $\begin{array}{c}-20 \div+45^{\circ} \mathrm{C} \\
\text { Remote control }\end{array}$ \\
\hline HPU $\left({ }^{1}\right)$ & $\begin{array}{c}1.77 \times 1.15 \times 1.71 \\
(\mathrm{~L} \times \mathrm{W} \times \mathrm{H})\end{array}$ & 20 & & & & $\begin{array}{c}325 \mathrm{bar} \\
75 \mathrm{~kW}(3 \times 380 \mathrm{~V}-50 \mathrm{~Hz})\end{array}$ \\
\hline Sheave & $1.05(\varnothing)$ & 0.2 & & $100\left({ }^{\mathrm{d}}\right)$ & & $\begin{array}{c}\text { Instrumented } \\
\text { (cable out, pull, speed) }\end{array}$ \\
\hline Cable & $\begin{array}{c}0.0254(\varnothing) \\
4000 \text { (length) }\end{array}$ & $\begin{array}{c}22\left(^{\mathrm{e}}\right) \text { (in air) } \\
18\left(^{(}\right) \text {(in water) }\end{array}$ & & $\begin{array}{l}89\left({ }^{\mathrm{d}}{ }^{\prime}\right) \\
205\left({ }^{f}\right)\end{array}$ & & $\begin{array}{c}3 \text { optic fibres } \\
3 \times 3000 \text { VAC-6A }\end{array}$ \\
\hline
\end{tabular}

$\left({ }^{1}\right)$ Hydraulic Pump Unit; $\left({ }^{a}\right)$ 1st layer; $\left({ }^{b}\right)$ 10th layer; $\left({ }^{c}\right)$ static, top layer; $\left({ }^{d}\right)$ working load; $\left({ }^{e}\right) \mathrm{kN} / \mathrm{km}$; $\left({ }^{\mathrm{f}}\right)$ breaking strength. 


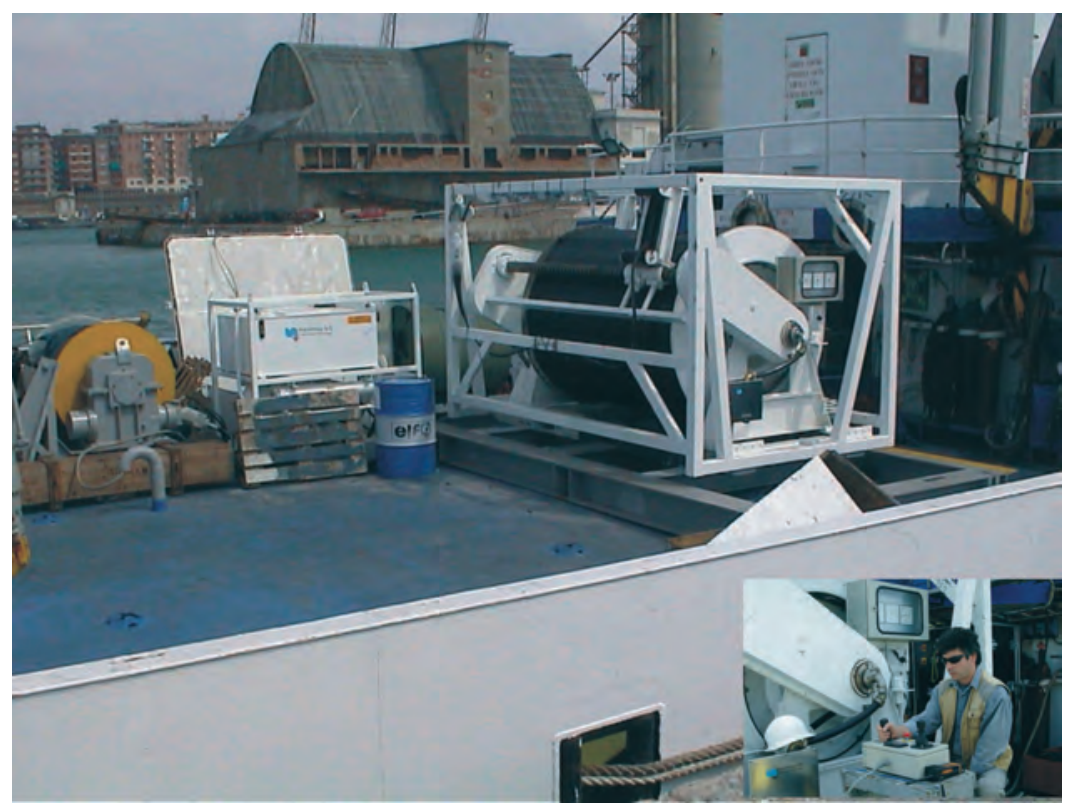

Fig. 4. The GEOSTAR handling system: power unit (right), cable spooled on the winch (left) and system console (insert) .
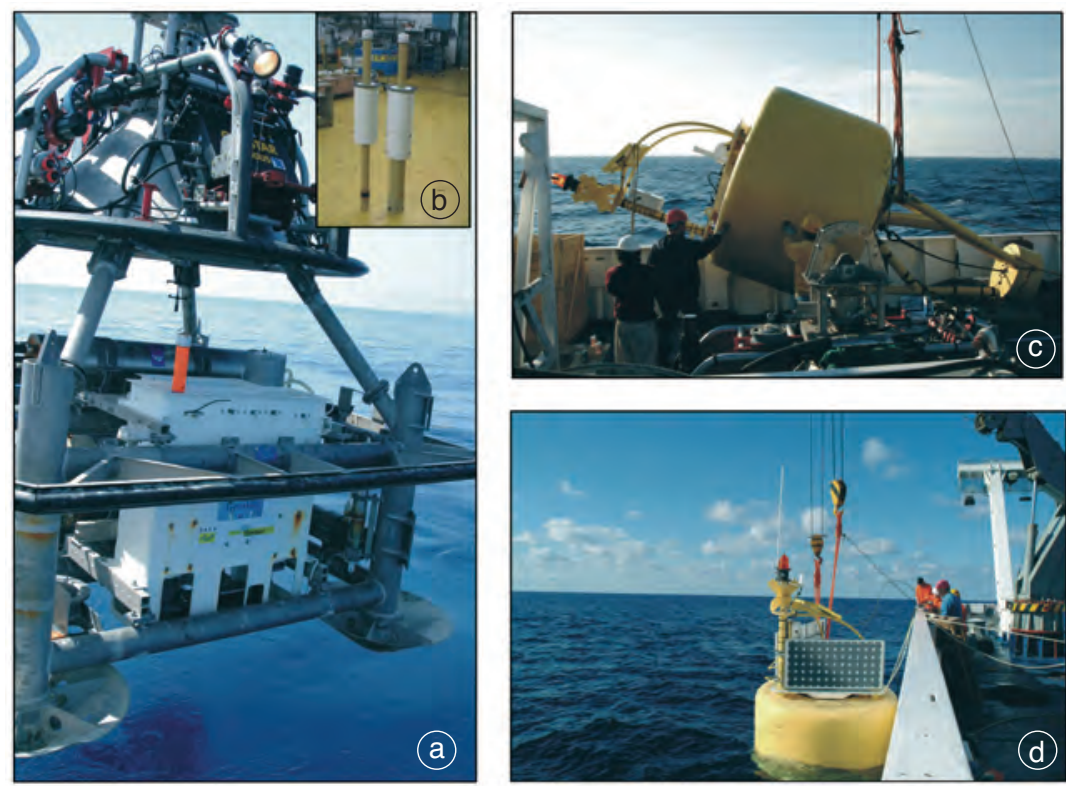

Fig. 5a-d. a) Messengers installed on the Bottom Station (height $1.3 \mathrm{~m}$ ); b) Messengers Storage and Expendable-type in Brest IFREMER Laboratory; c) surface buoy (weight: $35 \mathrm{kN}$; volume: $5 \mathrm{~m}^{3}$ ) GEOSTAR-2 version on board R/V Urania; d) surface buoy ORION-GEOSTAR-3 version just deployed. 
with a ship of opportunity or moored buoy, called MATS-12 (frequency: $12 \mathrm{kHz}$; speed: up to $2400 \mathrm{bit} / \mathrm{s}$ ). A surface relay buoy, equipped with a surface telemetry unit and radio/satellite transmitters, assures the (near)-real-time communication between a shore station and the observatory on the seafloor. Pictures of the MESSENGERS and the buoy are shown in fig. 5a-d.

\section{Single-frame systems derived from GEOSTAR}

\section{1. $S N-1$}

$\mathrm{SN}-1$ is a reduced-size version of GEO-STAR (fig. 6) and represents the recent effort of Italian marine research and technology addressed to the
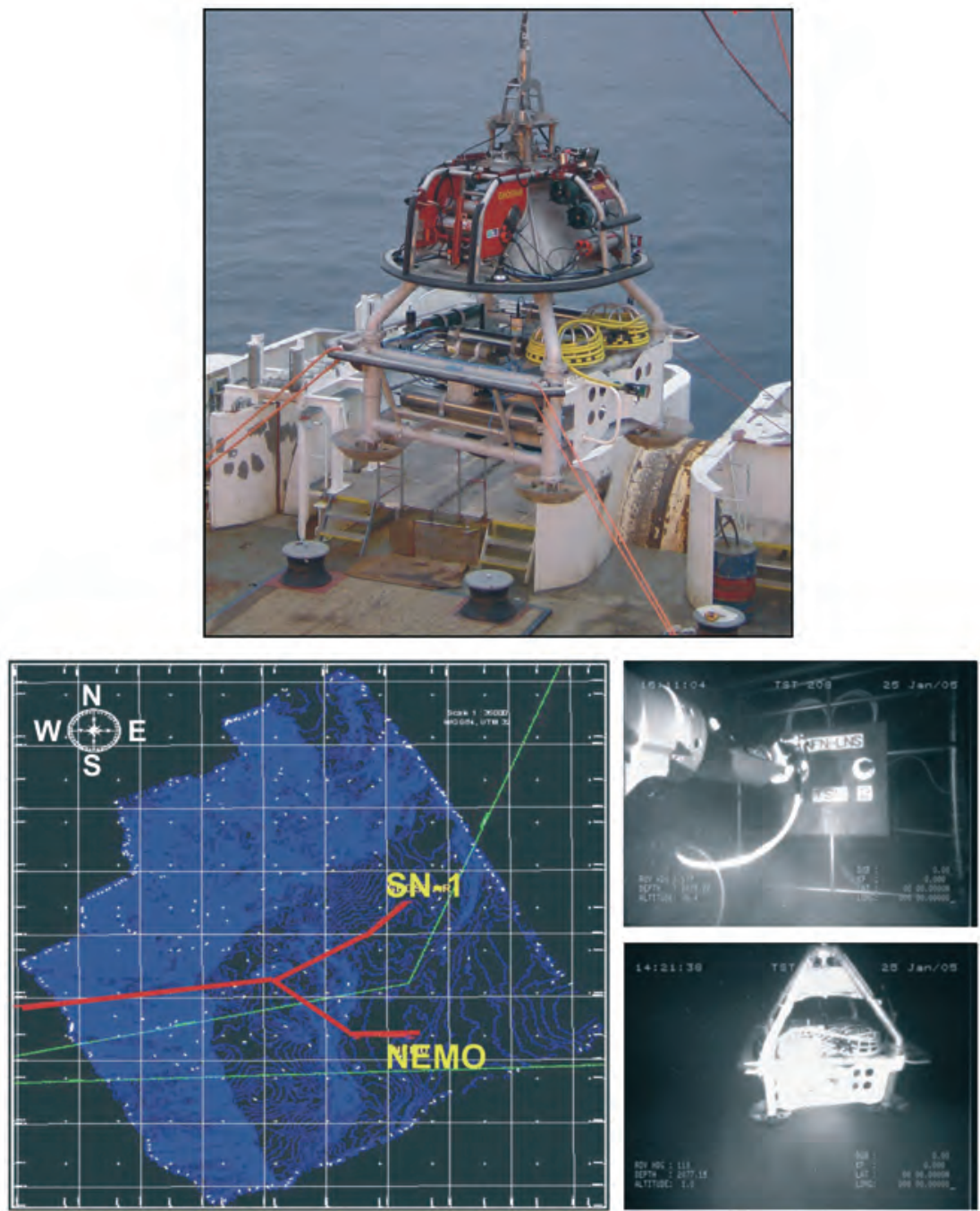

Fig. 6. SN-1 and MODUS (left) on the deck of the cable-vessel Pertinacia before deployment; the ROV connecting SN-1 Observatory to the cable interface (top-right); $\mathrm{SN}-1$ on the seafloor during the cable connecting operations (bottom-right). The cable route from Catania harbour to $25-\mathrm{km}$ east in the Ionian Sea is shown in top-left panel. 
development of a seafloor network around Italy (Favali and Beranzoli, 2006). SN-1 has the same features as GEOSTAR in regard to deployment/ recovery procedures based on MODUS, the data acquisition system (SN-1 DACS, see table II) and the special device for seismometer installation developed in the GEOSTAR projects (see Section 5 for details). Compared with GEOSTAR, SN-1 hosts a reduced set of sensors, mainly seismological and oceanographic. Like GEOSTAR, SN-1 has a vertical acoustic link from the seafloor to a surface unit managed by a ship of opportunity, while it is not supported by a surface-moored buoy. From October 2002 to May 2003 SN-1 successfully completed the first long-term experiment off-shore from Catania (Southern Italy, Eastern Sicily) at $2105 \mathrm{~m}$ w.d. in autonomous mode (Favali et al., 2003).

After this experiment, $\mathrm{SN}-1$ was fitted with a fibre-optic telemetry interface so as to be compatible with the electro-optical cable owned and deployed off-shore from Catania by INFN. In January 2005, the observatory was deployed at the same site as the first mission (about $25 \mathrm{~km}$ East from Catania at $2060 \mathrm{~m}$ w.d.) by MODUS and connected to the submarine cable. The sea operations were carried out using the C/V Pertinacia (Elettra Tlc SpA) and the $\mathrm{SN}-1$ connection was performed by the on-board deep-rated ROV. $\mathrm{SN}-1$ receives power from the shore, can communicate in real-time with the shore station located in the LNS-INFN laboratory inside Catania harbour, and is integrated in the INGV landbased networks. SN-1 is the first real-time seafloor observatory in Europe and one of the few in the world. It is also the first seafloor observatory operative in one of the «key-sites» planned in the EC project ESONET (Priede et al., 2003, 2004). These achievements were fulfilled thanks to a MoU between INGV and INFN, which is going to use the site for the NEMO pilot experiment addressed to the underwater detection of neutrinos (Favali et al., 2003; Favali and Beranzoli, 2006).

\section{2. $G M M$}

Designed and built within the framework of the ASSEM project (Blandin et al., 2003), GMM is another system developed on the basis of the GEOSTAR experience (Marinaro et al., 2004). GMM is an autonomous station designed to monitor the gas seawater concentration close to the seabed. GMM is based on a light benthic circular tripod of aluminium alloy (fig. 7). It can also operate interfaced to external units (e.g., other seafloor nodes of an underwater network, on-shore stations) via a submarine cable. The system can be reconfigured either to be integrated in more complex observatories (like GEOSTAR) or operated as a payload of submarine vehicles for surveys. In particular, the GMM design allows for modification of the frame-top and the installation of the mechanical interface to be managed during deployment/recovery procedures by MODUS. GMM electronics performs similar tasks as the GEOSTAR DACS (see table II).

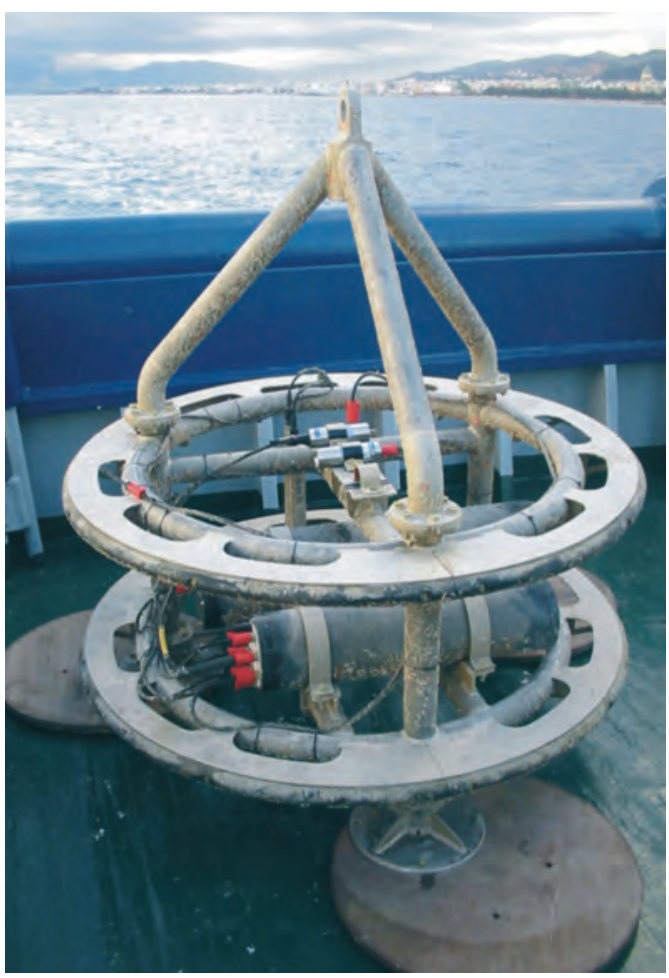

Fig. 7. GMM module on the ship before the deployment in the Corinth Gulf. 


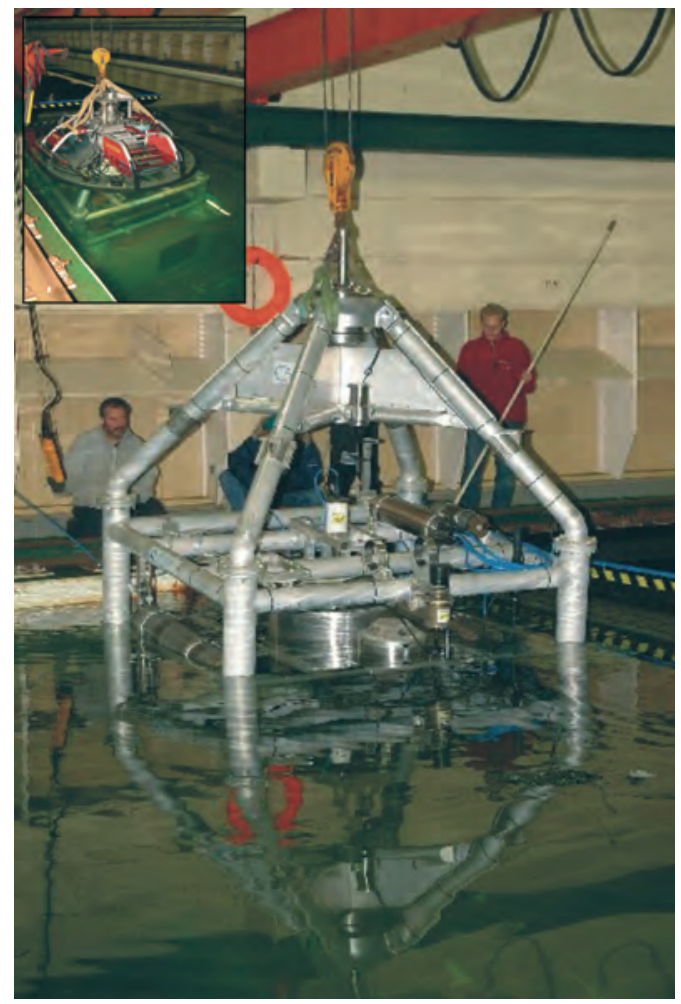

Fig. 8. MABEL during the low temperature tests at HSVA Basin in Hamburg.

\section{3. $M A B E L$}

MABEL is another deep-sea multiparameter seafloor observatory under development specifically addressed to the acquisition of geophysical, geochemical, oceanographic and environmental time series in polar regions (Calcara et al., 2001). MABEL, sponsored by the Italian PNRA, is designed to operate autonomously for at least one year and will be the first seafloor observatory deployed in Antarctica. The characteristics of its DACS are shown in table II. Its mechanical and electronic behaviour at low temperatures was already tested in 2002 at HSVA Basin (Hamburg) in simulated polar conditions (air: $-15^{\circ} \mathrm{C}$, and icy waters: $-2^{\circ} \mathrm{C}$ ) (fig. 8; Cenedese et al., 2004). The first Antarctic MABEL experiment started at the end of the 2005 having deployed the observatory in the Weddell Sea at over $1800 \mathrm{~m}$ w.d., with the logistic support of the R/V Polarstern managed by AWI, and it will last for at least one year.

\section{ORION-GEOSTAR-3 system}

Within the framework of the EC ORIONGEOSTAR-3 project, the GEOSTAR Bottom Station, the surface relay buoy and MODUS have been upgraded in order to be able to manage a network of GEOSTAR-class observatories, as a significant step towards deep-sea networking (Beranzoli et al., 2004). Two additional observatories have been developed (ORION Nodes 3 and 4) being able to communicate via acoustics with GEOSTAR Bottom Station. The communication system has been implemented in order to enable the GEOSTAR Observatory to operate as the main node (gateway) of the ORION network, exchanging data and status parameters with the satellite nodes and transferring data to the sea surface. A picture with the general scheme of ORION-GEOSTAR-3 is shown in fig. 9 .

The Bottom Station has thus also been equipped with horizontal acoustics devoted to the communication among the nodes, based on MATS modems. Through the horizontal communication, GEOSTAR receives automatic messages from the satellite nodes, while the vertical communication to the surface buoy, enhanced with respect to the original version, is used to transmit data from both GEOSTAR and the nodes. Connection between the buoy and a shore station is ensured by radio and satellite links. Data, specifically pieces of seismic waveforms, can be retrieved on request. The horizontal modems use omni-directional transducers, whereas the vertical acoustic link is based on directional transducers. The buoy transmission system (DRTS) comprises an electronic unit (MEU) managing the communications and interfacing the acoustic transmission system with two buoy-to-shore data links, VHF radio or IRIDIUM satellite. In case of VHF-link failure, a switch to the satellite transmission is automatically performed. 


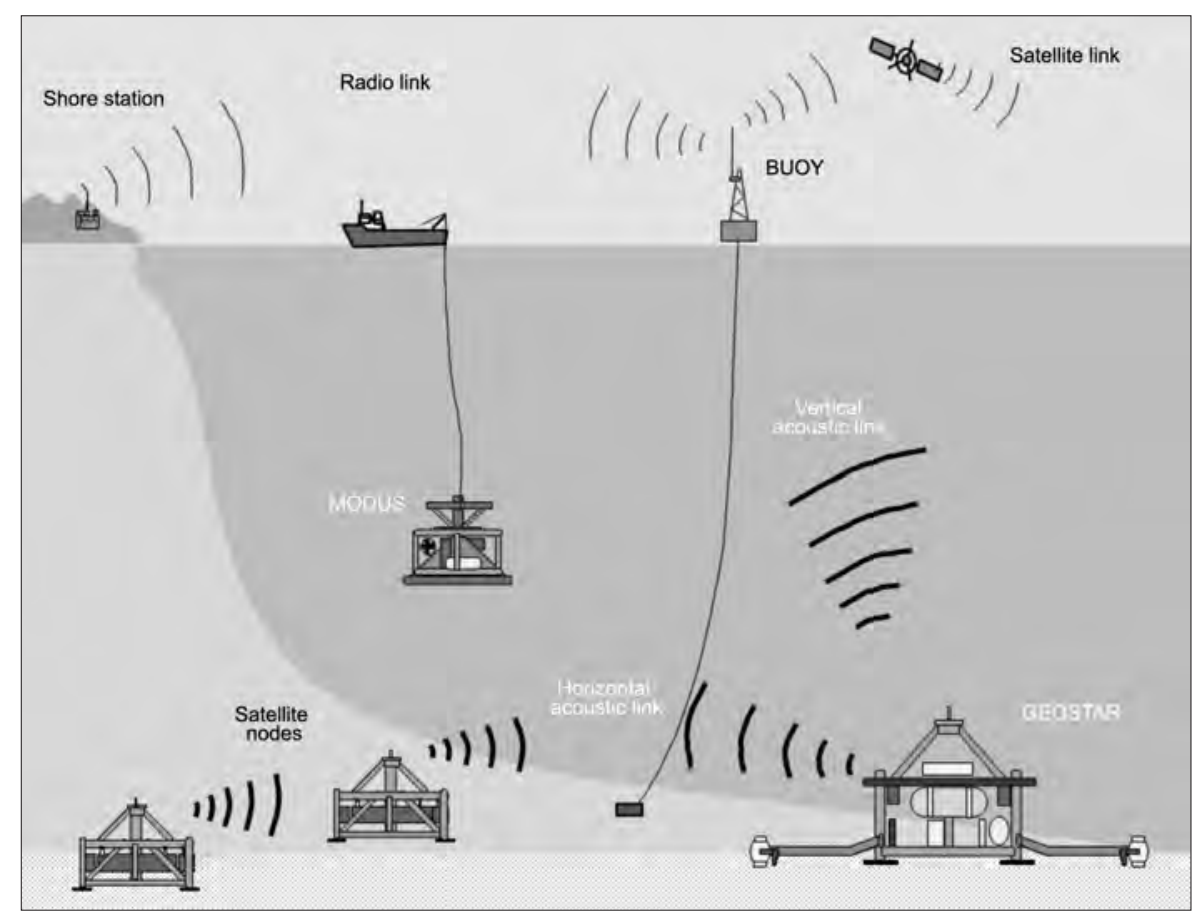

Fig. 9. Scheme of management and operation of the ORION-GEOSTAR-3 deep-sea network of GEOSTARclass seafloor observatories.

Table V. List of the GEOSTAR-class platforms and some specifications.

\begin{tabular}{ccccc}
\hline \hline Platform & $\begin{array}{c}\text { Overall dimensions }(\mathrm{m}) \\
(L \times W \times H)\end{array}$ & $\begin{array}{c}\text { Weight }(\mathrm{kN}) \\
\text { in air })\end{array}$ & $\begin{array}{c}\text { Weight }(\mathrm{kN}) \\
\text { (in water })\end{array}$ & Depth rated $(\mathrm{m})$ \\
\hline GEOSTAR & $3.50 \times 3.50 \times 3.30$ & 25.4 & 14.2 & 4000 \\
SN-1 & $2.90 \times 2.90 \times 2.90$ & 14.0 & 8.5 & 4000 \\
ORION Node 3 & $2.90 \times 2.90 \times 2.90$ & 14.0 & 8.5 & 4000 \\
ORION Node 4 & $2.00 \times 2.00 \times 2.00$ & 6.6 & 3.4 & 1000 \\
GMM & $1.50 \times 1.50 \times 1.50$ & 1.5 & 0.7 & 1000 \\
MABEL & $2.90 \times 2.90 \times 2.90$ & 14.0 & 8.5 & 4000 \\
\hline
\end{tabular}

To achieve the new required functionality, the DACS has been properly enhanced (Beranzoli et al., 2004). The sampling rate of some sensors (e.g., gravity meter) has been increased and new sensor packages installed (e.g., electrode analyser, hydrophone). Accordingly, addi- tional acquisition channels have been made available. The following function was implemented: automatic event detection on the seismometer and hydrophone data, transmission of seismometer waveforms. The DACS interface to the communication system was properly en- 
hanced in order to make data and status parameter available for transmission to the communications system. The communications can be started by any of the ORION-GEOSTAR-3 network nodes. The DACS hardware has been also upgraded in order to increase functions/capabilities and reliability with reduced power and volume requirements (see table II): a) new CPU boards with increased power; b) new status boards with additional sensors, scientific data acquired at 24 bits; c) status sensors acquired at 16 bits (12 bits in the previous version); d) boards managing up to $32 \mathrm{~Gb}$ on hard disk and 1 Gbyte on flash card (see table II).

As already mentioned, the EC requested the ORION-GEOSTAR-3 and ASSEM networks to be compatible. Accordingly, common communication protocols were defined and implemented in the nodes of both networks in regard to data communication. For this purpose, an ORION node (Node 4) was deployed and tested together with the ASSEM nodes in the Corinth Gulf pilot experiment.

The list of the GEOSTAR-class platforms with some specifications are summarised in table V.

\section{Experiments, data and prototyping activity}

The sea experiments performed are depicted in table VI including specific information and the sensors used in each experiment. Figure 10 shows the map of the locations. All the experiments were carried out by means of mediumsize vessels with dGPS and DP, like, for instance, the CNR R/V Urania. Only for the deployment of $\mathrm{SN}-1$ and its connection to the electro-optical cable was a larger cable vessel used (C/V Pertinacia).

GEOSTAR performed its first sea demonstration mission in shallow waters in 1998 (Jourdain, 1999; Beranzoli et al., 2000a,b). The observatory was deployed on the seafloor of the Adriatic Sea (Northern Italy) about 50-km east of Ravenna harbour. The selection of the mission site was based both on the knowledge of geological and geotechnical soil characteristics (flat and consolidated seabed, distance from turbulence sources, absence of pockmarks and gassy sedi- ments) and safety factors (shallow water depth, vicinity to harbour logistics). The starting mission procedure foresaw that after the Bottom Station had touched down, all the sensor packages and devices were switched on through MODUS telemetry and their correct functioning was checked. After the positive outcome of this operation, the Bottom Station was released by MODUS and left on the sea bottom (Beranzoli et al., 2000a,b). During the shallow water demo mission around $346 \mathrm{Mb}$ of data were acquired over roughly 440 operational hours, corresponding to $98 \%$ of the mission's duration, see table VI for the list of the used sensors. An expandable MESSENGER was automatically released and transmitted data via the ARGOS satellite. A storage MESSENGER was release acoustically just before the Bottom Station's recovery. The experiment demonstrated the functionality of the whole system, including MODUS. Temporary magnetic and seismological stations were also installed on land as a reference for GEOSTAR measurements. Analysis of data acquired, even if during only 21 days, pointed out the reliability of the measurements and their scientific potentiality as a unique time-referenced multiparameter data. Some interesting events, like regional earthquakes, water current and thermocline depth variations, and a magnetic storm were recorded (Beranzoli et al., 2003).

The first GEOSTAR long-term deep-sea mission was performed between September 2000 and April 2001 at about 2000 m w.d. in Southern Tyrrhenian Sea (see table VI). The communication system was enhanced adding a surface moored buoy, equipped with the interface of the acoustic system and a radio/satellite link for (near)-real-time transmission between the Bottom Station and on-shore sites. Data acquired, $4160 \mathrm{~h}$ corresponding to about 174 days (out of 205 because the batteries were exhausted), amount to more than $65 \mathrm{Mb}$ mostly from the gravity meter. An external self-recording hydrophone acquired $4 \mathrm{~Gb}$ of data. Also in this longterm experiment, the data quality was high, as demonstrated by De Santis et al. (2006), Iafolla et al. (2006), and Etiope et al. (2006) pointed out ocean-lithosphere interactions at BBL level.

During the 2002-2003 experiment off-shore from Catania (Southern Italy, Eastern Sicily; 
Table VI. List of the seafloor experiments performed with GEOSTAR-class platforms and the sensors used (see fig. 10 for the map).

\begin{tabular}{lcccc}
\hline \hline Experiments & $\begin{array}{c}\text { Location } \\
(\mathrm{m})\end{array}$ & Depth Year(s) & Days Platform(s) & Sensors used \\
\hline
\end{tabular}

\begin{tabular}{cccc}
\hline $\begin{array}{c}\text { GEOSTAR } \\
\text { (demo mission) }\end{array}$ & $\begin{array}{c}\text { Northern Adriatic } \\
\text { Sea (Italy) }\end{array}$ & 42 & 1998 \\
& & \\
& & \\
& & \\
GEOSTAR-2 ( & & \\
(1st deep-sea & Southern Tyrrhenian & 1950 & 2000 \\
mission) & Sea (Italy) & 2001
\end{tabular}

21 GEOSTAR Three-component broad-band seismometer; scalar magnetometer; fluxgate magnetometer (only $X-Y$ ); ADCP $300 \mathrm{kHz}$; CTD; transmissometer; precision tilt meter $(X, Y)$.

205 GEOSTAR Gravity meter; scalar magnetometer; tri-axial fluxgate magnetometer; ADCP 300 kHz; CTD; transmissometer; tri-axial single-point current meter; precision tilt meter $(X, Y)$; water sampler (off-line); hydrophone (off-line). ( ${ }^{2}$ )

\begin{tabular}{|c|c|}
\hline $\begin{array}{c}\mathrm{SN}-1 \\
\text { (first mission) }\end{array}$ & $\begin{array}{l}\text { Western Ionian Sea } 2105 \\
\text { (off-Eastern Sicily, } \\
\text { Italy) }\end{array}$ \\
\hline
\end{tabular}

$213 \quad$ SN-1
$\begin{array}{llll}40 & 2004 & 198\left({ }^{3}\right) & \text { GMM } \\ 2005 & \end{array}$

(pilot experiment, (Greece) in a pockmark)

\begin{tabular}{|c|c|c|}
\hline $\begin{array}{l}\text { ASSEM } \\
\text { (pilot experiment) } \\
\text { (ORION-GEO- } \\
\text { STAR-3 -ASSEM } \\
\text { clustering) }\end{array}$ & $\begin{array}{l}\text { Gulf of Corinth } \\
\text { (Greece) }\end{array}$ & 380 \\
\hline $\begin{array}{l}\text { ORION-GEO } \\
\text { STAR-3 (deep- } \\
\text { sea networking) }\end{array}$ & $\begin{array}{l}\text { Tyrrhenian Sea } \\
\text { (Marsili seamount, } \\
\text { Italy) }\end{array}$ & 3320 \\
\hline
\end{tabular}

Three-components broad-band seismometer; hydrophone; gravity meter; CTD; tri-axial single-point current meter.

$\mathrm{CH}_{4}$ sensors (3); $\mathrm{H}_{2} \mathrm{~S}$ sensor; CTD.
214 ORION Node 4

$477\left({ }^{4}\right)$ GEOSTAR (G) and ORION Node 3 (N3)

Three-component broad-band seismometer; hydrophone; $\mathrm{CH}_{4}$ sensor.

Three-comp. broad-band seismometers (G, N3); hydrophones $(\mathrm{G}, \mathrm{N} 3)$; gravity meter $(\mathrm{G})$; scalar magnetometer $(\mathrm{G})$; tri-axial fluxgate magnetometer $(\mathrm{G})$;

ADCP $300 \mathrm{kHz}(\mathrm{G})$; CTD (G); transmissometer $(\mathrm{G})$; tri-axial singlepoint current meter $(\mathrm{G}) ; p H$ sensor $(\mathrm{G})$; precision tilt meter $(X, Y)(\mathrm{G})$; water sampler (off-line) $(\mathrm{G})$.

NEMO - SN-1 Western Ionian Sea 20602005 Ongoing SN-1 (cabled January (off-Eastern Sicily, 25, 2005) Italy)
Three-component broad-band seismometer $\left({ }^{5}\right)$; hydrophone; gravity meter; scalar magnetometer; CTD; tri-axial single-point current meter.

(') This experiment included originally also a three-component broad-band seismometer and a chemical analyser prototype. These instruments were not used in the experiment, due to failures that occurred during the sea operations preceding deployment; $\left({ }^{2}\right)$ provided by IFM-GEOMAR; $\left({ }^{3}\right)$ 91days from April 26 to July 26, 2004, and 107 days from September 29, 2004 to January 14, 2005; $\left({ }^{4}\right) 134$ days from December 14, 2003 to April 26, 2004, and 337 days from June 14, 2004 to May 23, 2005; $\left(^{5}\right)$ installed in a titanium sphere. 


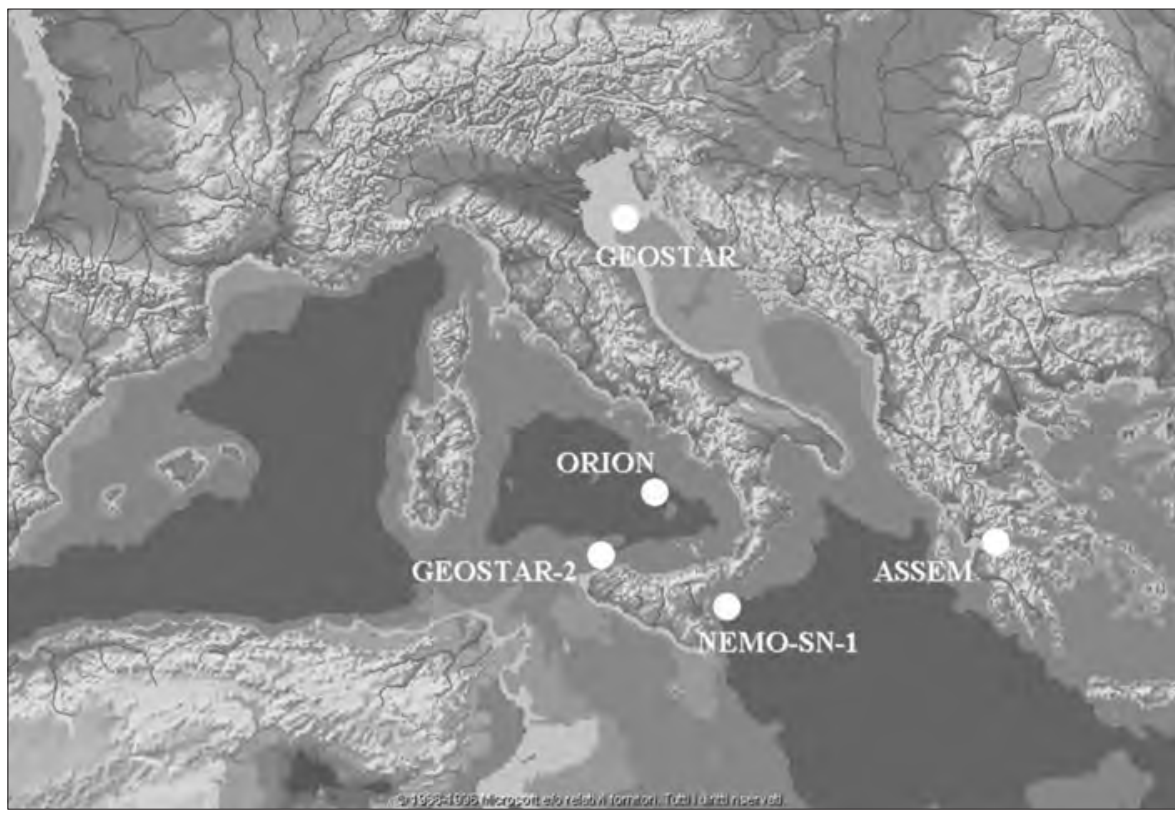

Fig. 10. Map of the seafloor experiments performed with GEOSTAR-class platforms, see table VI for details.

table VI), SN-1 acquired in autonomous mode, around $10 \mathrm{~Gb}$ of data, $7.65 \mathrm{~Gb}$ of which belong to $100 \mathrm{~Hz}$ sampling rate broad-band seismometer, Guralp CMG-1T (Favali et al., 2003). The double housings of seismometer, comprising a titanium benthosphere inside an external bell, and the relative simple procedure to release it allowed protection from sea-current effects and good coupling of the instrument to the seabed. These solutions, already used in the previous GEOSTAR experiments, were validated and allowed to collect high-quality seismological data (Monna et al., 2005). The signals showed noise in the underwater environment (Webb, 1998) with a level comparable with «quiet» terrestrial seismic stations, well within the high and low background noise reference models (Peterson, 1993). It is worth noting that in our case, unlike the ocean experiments, long-period noise on the vertical component caused by infragravity waves is not a first-order effect. In fact, the energy of infragravity waves in the Mediterranean Sea is small as compared with the Pacific and Atlantic oceans. Thanks to its good $\mathrm{S} / \mathrm{N}$ ratio $\mathrm{SN}-1$ demonstrated the relevant improvement of the seismic event detection recording hundreds of local events not recorded by the dense on-land networks (Favali et al., 2004b). Examples of the data collected are shown in fig. 11a-f.

GMM was deployed in an active pockmark in the Gulf of Patras (Corinth Shelf, Greece) in April 2004 as one of the nodes of the ASSEM system (see table VI). The system was simply lowered down to the seafloor $(40 \mathrm{~m}$ w.d.) with a mechanical cable and positioned in the right place by divers. GMM was linked to a submarine cable for real-time data transmission to an on-shore modem. The $12 \mathrm{~V}, 960$ Ah lithium battery pack made six-month autonomous operation possible. A remote link to the on-shore modem was active for the system checks and data retrieval. Through this daily link, a malfunctioning in all of the methane sensors was detected at the end of July, so the system was recovered at the end of September, the $\mathrm{CH}_{4}$ and $\mathrm{H}_{2} \mathrm{~S}$ sensors were replaced, and the mission re-started after one day. GMM was operating until mid-January 2005. Data analysis is in progress. 

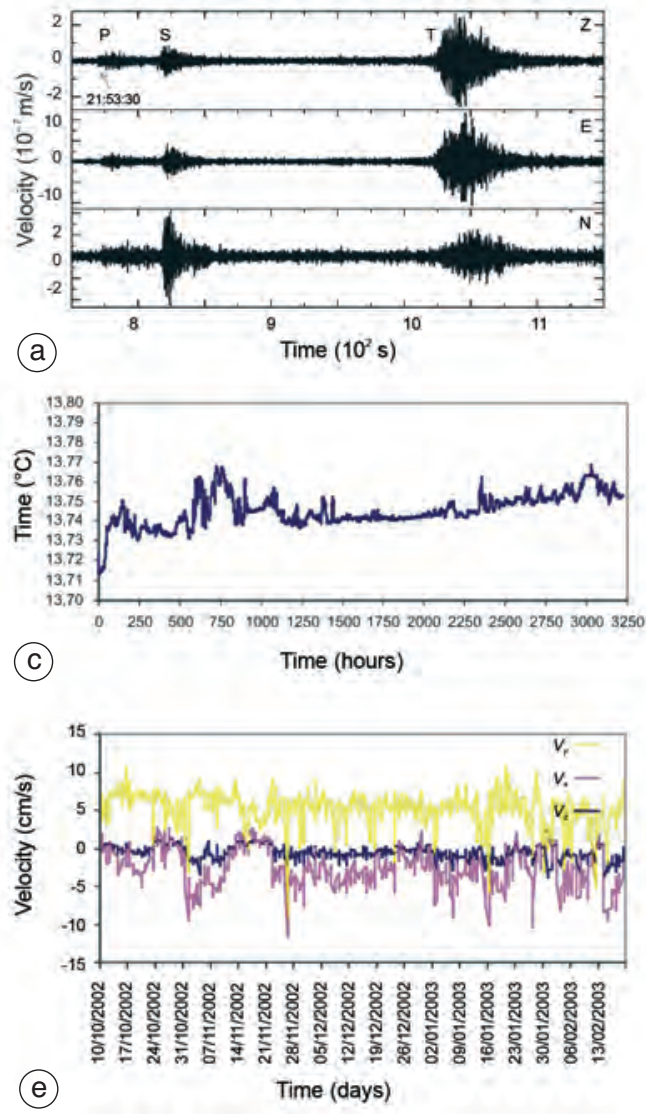
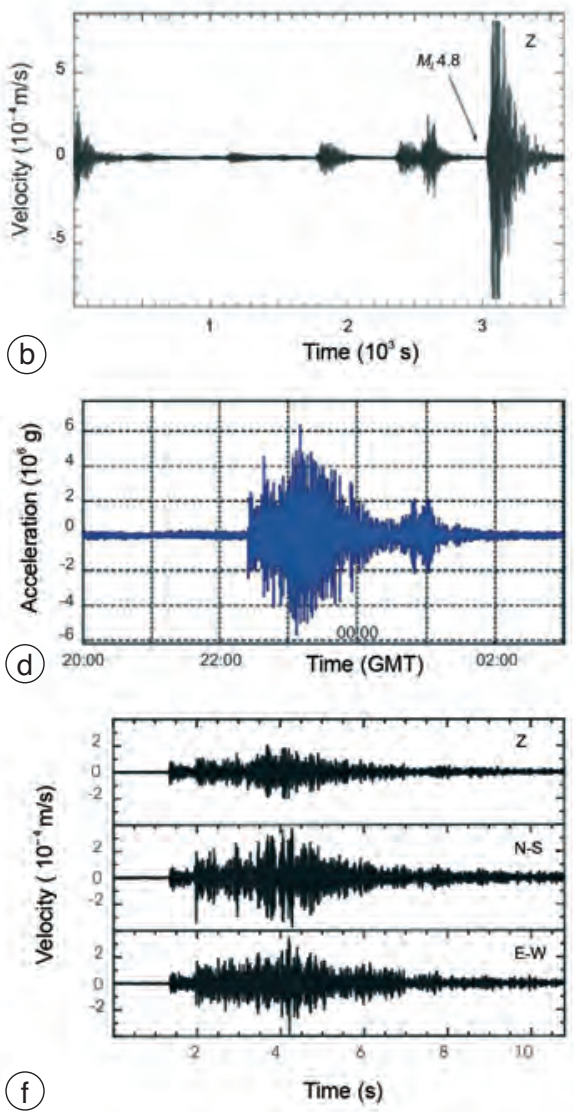

Fig. 11a-f. SN-1 measurements acquired in Ionian Sea at over $2000 \mathrm{~m}$ w.d. in stand-alone mode (first mission, 2002-2003) and in real-time acquisition mode (cable connected, since end of January 2005): a) regional earthquake of 27 December 2002, not reported by land-network bulletins, showing $P_{-}, S-$, and $T$-phase arrivals; b) 2002-2003 Mt. Etna eruption, seismic activity of the volcano over one hour (27 October, 2002, 2:00-3:00 a.m.), including the major event of the sequence $\left(M_{L}=4.8\right)$; c) temperature measured by CTD sensor over the mission period (the mean value is around $\left.13.74^{\circ} \mathrm{C}\right)$; d) teleseism occurred in Kuril Islands $\left(M_{w}=7.3\right)$ and recorded by the gravity meter on 17 November, 2002; e) water current velocity components over the mission period, the N-S component, running along the Sicilian coast from/to the Messina Strait shows the most significant values (in average $5 \mathrm{~cm} / \mathrm{s})$; f) real-time acquired waveforms of the 28 March, 2005 Sumatra earthquake $\left(M_{w}=8.7\right)$.

The first long-term mission of the ORIONGEOSTAR-3 deep-sea network started in December 2003 (see table VI and fig. 12). The deployment site lies in the Southern Tyrrhenian Sea at more than $3300 \mathrm{~m}$ w.d. at the NW base of the Marsili complex volcanic seamount, one of the largest seamounts of the Mediterranean Basin (Marani et al., 2004). The network configuration for this mission includes GEOSTAR as main node and one satellite (ORION Node 3) in horizontal acoustic communication with GEOSTAR deployed $1 \mathrm{~km}$ apart. A surface buoy enables the connection with GEOSTAR via vertical acoustics and the radio/satellite link with the on-shore station located at the INGV observatory of Gibilmanna (northern coast of Sicily). Due to a malfunctioning in the acoustic communication link with the nodes (underwater 
part), they were recovered at the end of April 2004 and re-deployed at the same site at the middle of June until the final recovery in May 2005, always using the R/V Urania. Examples of the collected data are shown in fig. 13a-d.

Parallel to sea experiments with the GEOSTAR-class platforms, sensor prototypes also had to be developed, due to the lack of reliable instruments to collect long-time data series especially in the deep-sea environment. A fluxgate magnetometer (first version bi-axial, then tri-axial) built at INGV and subsequently manufactured industrially by Tecnomare (a company of Eni Group) has been successfully used since GEOSTAR demo mission. Its resolution is 0.1 $\mathrm{nT}$, the absolute accuracy $5 \mathrm{nT}$, and the power consumption reduced to $2 \mathrm{~W}$. The thermal drift of the three-component magnetometer $(0.2-0.5$ $\mathrm{nT} /{ }^{\circ} \mathrm{C}$ for typical fluxgate magnetometers) is expected to be negligible because the sea temperature is quite constant at the working depths of more than $2000 \mathrm{~m}$, within a fraction of $1^{\circ} \mathrm{C}$.
Another prototype is a gravity meter derived from a prototype built for space applications, its marine version was developed in a joint venture between INGV and IFSI-INAF, and has been successfully used since GEOSTAR-2's first deep-sea mission in the Tyrrhenian Sea. The main characteristics of the gravity meter are sensitivity $10^{-9} \mathrm{~g} \mathrm{~Hz}^{-1 / 2}$; frequency range $10^{-5}$ to $10^{-1} \mathrm{~Hz}$; power consumption $300 \mathrm{~mW}$; volume $10 \mathrm{~cm}^{3}$; weight $2 \mathrm{~kg}$ (Iafolla and Nozzoli, 2002). The last prototype developed and tested both in the laboratory and in the deep- sea (in the ORION-GEOSTAR-3 project) is an automatic electrode analyser. This analyser with self-calibrating capability is capable of performing longterm (six months) experiments. The instrument was developed and validated in a joint activity between INGV and Tecnomare. At present, it is equipped with a $p H$ electrode (AMT), which is the only commercially electrode for the deepsea, but it can be equipped with other electrodes. The main characteristics of $p H$ electrode

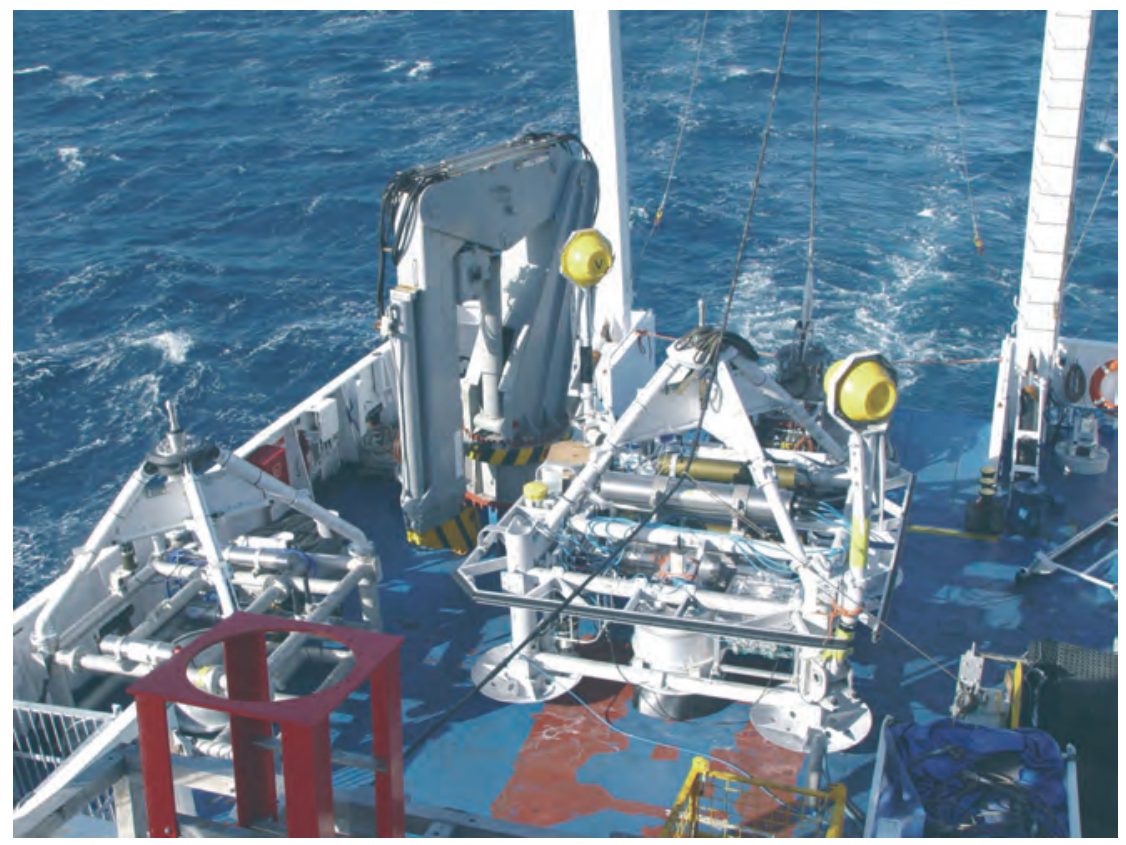

Fig. 12. GEOSTAR gateway seafloor observatory (right) and ORION Node 3 (left) on the deck of the R/V Urania before the deployment at the base of Marsili underwater volcano (ORION-GEOSTAR-3 first mission). 

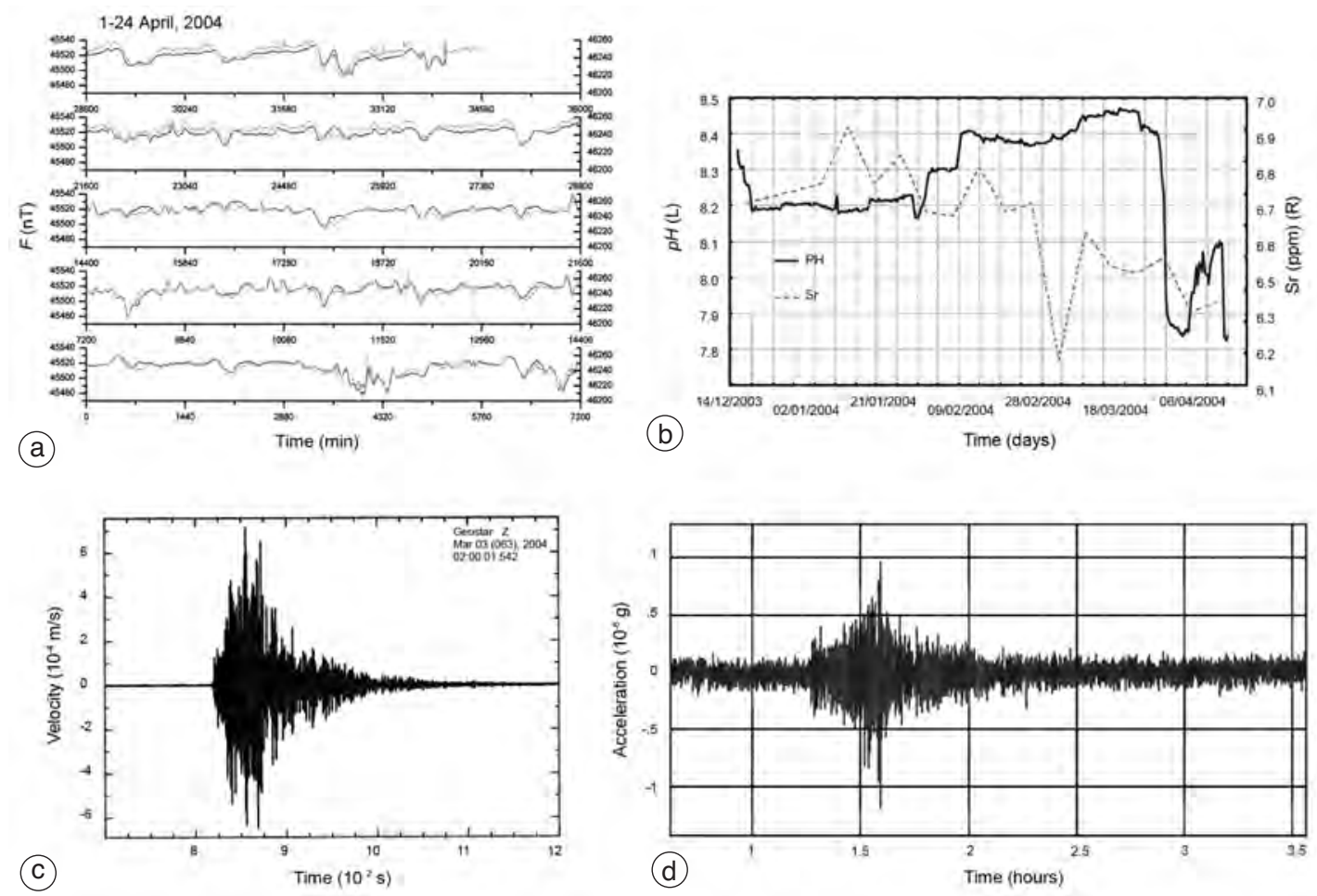

Fig. 13a-d. ORION network measurements acquired at the base of the Marsili seamount: a) one month of magnetometer measurements (April 2004, red line) compared with the Italian land reference observatory (L'Aquila) in Central Italy; b) $p H$ measurements by the electrode analyser compared with the chemical analysis (Stronzium) performed on the samples collected by the water sampler; c) local event of the Southern Tyrrhenian Sea (3 March 2004, $M_{L}=4.6$ ) recorded by the seismometer; d) teleseismic event recorded by the gravity meter (26 December 2003, $M_{S}=6.8$, Iran).

are in $p H$ units: range 2 to 11 ; accuracy 0.05 ; resolution 0.01 . The electrode can operate at the maximum pressure of $600 \mathrm{bar}$, and at a $T$ range from -2 to $+38^{\circ} \mathrm{C}$. All these prototypes are managed by the DACS. Other sensors, like a nuclear spectrometer, are undergoing development.

\section{Conclusions}

GEOSTAR, derived platforms and the ORION-GEOSTAR-3 deep-sea observatory network, have been tested during long-term missions (maximum duration over 330 days). The assets of these platforms lie in the reliability of the whole system, the chance to have (near)-realtime communications, and the data quality. The chance to perform quick comparisons of unique time-referenced data series of different sensors makes the development of multiparameter data analysis quite easy. The GEOSTAR-class platforms represent a fleet of five seafloor observatories among the twenty-eight available worldwide already validated at sea (Favali and Beranzoli, 2006). These platforms are perfectly compatible and can be easily re-configured according to the specific applications. All these features fit the requirements outlined within the framework of specific programmes, such as the ESA-EU GMES joint programme. 


\section{Acknowledgements}

First of all, we are deeply indebted to the EC that supported our activities and funded many projects within the framework of the MAST and the Environment Programmes.

The Authors also wish to thank everyone who worked in the European and Italian projects (A) GEOSTAR (EC), (B) GEOSTAR-2 (EC), (C) ASSEM (EC), (D) ORION-GEOSTAR-3 (EC), (E) SN-1 (GNDT), (F) MABEL (PNRA):

INGV (co-ordinator: A, B, D, E and F; partner: C): Laura Beranzoli, Thomas Braun, Lili Cafarella, Massimo Calcara, Paolo Casale, Giuseppe D'Anna, Roberto D'Anna, Angelo De Santis, Domenico Di Mauro, Manuela Ditta, Giuseppe Etiope, Paolo Favali, Francesco Frugoni, Louis Gaya-Pique, Matteo Grimaldi, Cristina La Fratta, Nadia Lo Bue, Luigi Innocenzi, Luigi Magno, Giuditta Marinaro, Sabrina Mercuri (till 2003), Caterina Montuori, Stephen Monna, Paolo Palangio, Giuseppe Passafiume, Giovanni Romeo, Stefano Speciale, Tiziana Sgroi, Giuseppe Smriglio, Roberto Tardini, Roberta Tozzi.

ISMAR-CNR (partner: A, B, D and E): Fabiano Gamberi, Michael P. Marani.

Tecnomare SpA (partner: A, B, D, E and F; sub-contractor: C): Marco Berta (up to 1997), Ercole Boatto, Gian Mario Bozzo (till 2000), Daniele Calore (till 2004), Renato Campaci, Stefano Cenedese, Roman Chomicz, Felice Da Prat, Flavio Furlan, Francesco Gasparoni, Mascia Lazzarini, Andrea Marigo (till 1998), Luciano Pedrocchi, Carmelo Pennino (up to 1997), Walter Prendin, Fabio Zanon, Marco Zordan (till 2002).

TUB (partner: A, B, D, E and F): Günther Clauss, Haiko de Vries, Sven Hoog (till 2004), Jorg Kruppa, Peter Longerich.

TFH (partner: A, B, D, E and F): Hans W. Gerber, Wilfried Langner.

IFREMER (co-ordinator: C; partner: A, B and D): Yannick Aoustin, Jérôme Blandin, Gérard Guyader, Yvon Le Guen, David Le Piver, Gérard Loaëc, Jean Marvaldi, Roland Person, Christian Podeur, Jean-Francois Rolin.

LOB-CNRS (partner: A and B): Jean-Luc Fuda, Claude Millot, Gilles Rougier.
SERCEL-Underwater Acoustic Division, former ORCA Instrumentation (partner: A, B and D; sub-contractor: C): Gerard Ayela, Dominique Barbot, David Fellmann (till 2002), JeanMichel Coudeville, Michel Nicot, Alain Priou.

IFSI-INAF (partner: E; sub-contractor: B and D): Emiliano Fiorenza (till 2004), Valerio Iafolla, Vadim Milyukov, Sergio Nozzoli, Matteo Ravenna.

IPGP (partner: B and C): Pierre Briole, JeanPaul Montagner.

IFM-GEOMAR (partner: D): Joerg Bialas, Ernst R. Flueh.

OGS (partner: E and F): Renzo Mosetti, Marino Russi.

HCMR (partner: C): Vasilios Lykousis.

University of Patras (partner: C): Dimitris Christodoulou, George Ferentinos, George Papatheodorou.

CAPSUM Technologie GmbH (partner: C): Michel Masson.

NGI (partner: C): Per Sparrevik, James M. Strout.

FUGRO Engineers (partner: C): David Cathie.

University of Roma-3 (partner: E): Andrea Billi, Claudio Faccenna.

University of Catania (partner: E): Stefano Gresta.

University of Messina (partner: E): Giancarlo Neri.

University of Palermo (partner: E): Dario Luzio.

Special thanks to: Claudio Viezzoli and Marcantonio Lagalante (marine logistics); Capts. Emanuele Gentile and Vincenzo Lubrano, and the crew of R/V Urania, vessel owned by CNR and managed by So.Pro.Mar.; Capt. Alfio Di Giacomo and the crew of M/P Mazzarò, vessel owned by Gestione Pontoni SpA; Capt. Vincenzo Primo and the crew of C/V Pertinacia, owned by Elettra Tlc SpA (Giuseppe Maugeri, chief of mission).

The authors are very grateful to the reviewers for their comments able to greatly improve the clarity and quality of the paper.

This paper is dedicated to the memory of Luc Floury and Giuseppe Smriglio, who embarked on this adventure many years ago, believing in the potential of this «new» Science. 
List of acronyms and abbreviations used in the text

ABEL - Abyssal BEnthic Laboratory.

ADCP - Acoustic Doppler Current Profiler.

ARGOS - Advanced Research and Global Observation Satellite (WWW site: http://www.cls.fr/html/argos/ welcome_en.html).

ASSEM - Array of Sensors for long-term SEabed Monitoring of geo-hazards (WWW site: http://www.ifremer.fr/ assem).

AWI - Alfred-Wegener-Institut für Polar- und Meeresforschung (WWW site: http://www.awi-bremerhaven.de).

$\mathrm{BBL}$ - Benthic Boundary Layer.

CNR - Consiglio Nazionale delle Ricerche (http://www.cnr.it)

CNRS - Centre National de la Recherche Scientifique (WWW site: http://www.cnrs.fr).

CTD - Conductivity, Temperature and Depth.

C/V - Cable Vessel.

DACS - Data Acquisition and Control System.

DESIBEL - DEep-Sea Intervention on future BEnthic Laboratory (WWW site: http://dbs.cordis.lu/cordis-cgi/ srchidadb?caller=projadvancedsrch\&srch\&qf_ep_rcn_a $=27267$ \&action $=\mathrm{d}$ ).

dGPS - Differential Global Positioning System (WWW site: http://chartmaker.ncd.noaa.gov/staff/dgps.htm).

DP - Dynamic Positioning.

DRTS - Data Radio Transmission System.

EC - European Commission (WWW site: http://europa.eu.int/ comm).

ENI - Ente Nazionale Idrocarburi (WWW site: http:// www.eni.it).

ESA - European Space Agency (WWW site: http:// www.esa.int).

ESONET - European Seafloor Observatory NETwork (WWW site: http://www.abdn.ac.uk/ecosystem/esonet).

EU - European Union (WWW site: http://europa.eu.int).

GEOSTAR - GEophysical and Oceanographic STation for Abyssal Research (WWW site: http://www.ingv.it/ geostar/geost.htm)

GEOSTAR-2 - GEOSTAR 2nd Phase: deep-sea mission (WWW site: http://www.ingv.it/geostar/geost2.htm).

GMM - Gas Monitoring Module (WWW site: http:// www.ifremer.fr/assem/corinth/photo_gallery/photo_ gallery.htm).

GMES - Global Monitoring for Environment and Security (WWW site: http://www.gmes.info).

GNDT - Gruppo Nazionale per la Difesa dai Terremoti (WWW site: http://gndt.ingv.it).

HCMR - Hellenic Centre for Marine Research (WWW site: http://www.hcmr.gr).

HSVA - Hamburgische Schiffbau-VersuchsAnstalt GmbH (WWW site: http://www.hsva.de).

IFM-GEOMAR - Leibniz-Institut für Meereswissenschaften an der Universität Kiel (WWW site: http:// www.ifm-geomar.de).

IFREMER - Institut Français de Recherche pour l'Exploitation de la Mer (WWW site: http://www.ifremer.fr).

IFSI-INAF - Istituto di Fisica dello Spazio InterplanetarioIstituto Nazionale di Astrofisica (WWW site: http:// www.inaf.it).

INFN - Istituto Nazionale di Fisica Nucleare (WWW site: http://www.infn.it).

INGV - Istituto Nazionale di Geofisica e Vulcanologia
(WWW site: http://www.ingv.it).

IPGP - Institut de Physique du Globe de Paris (WWW site: http://www.ipgp.jussieu.fr).

ISMAR - Istituto di Scienze Marine-CNR, Sezione di Geologia Marina di Bologna (WWW site: http:// www.bo.ismar.cnr.it).

LNS - Laboratori Nazionali del Sud (WWW site: http:// www.lns.infn.it)

LOB - Laboratoire d'Océanologie et de Biogéochemie (WWW site: http://www.com.univ-mrs.fr/lob).

MABEL - Multidisciplinary Antarctic BEnthic Laboratory (WWW site: http://www.ingv.it/geostar/mabel.html).

MAST - MArine Science and Technology (WWW site: http://www.cor-dis.lu/mast).

MATS-12 - Multimodulation Acoustic Transmission System-12 kHz (WWW site: http://www.sercel.fr).

MEU - Multipurpose Electronic Unit.

MODUS - MObile Docker for Underwater Sciences

MoU - Memorandum of Understanding.

$\mathrm{M} / \mathrm{P}$ - Moto Pontoon.

NEMO - NEutrino Mediterranean Observatory (WWW site: http://nemoweb.lns.infn).

NGI - Norges Geotekniske Institutt (WWW site: http:// www.ngi.no).

NRC - National Research Council (WWW site: http:// www.nationalacademies.org/nrc).

OGS - Istituto Nazionale di Oceanografia e Geofisica Sperimentale (http://www.ogs.trieste.it).

ORION-GEOSTAR-3 - Ocean Research by Integrated Observation Networks (http://www.ingv.it/geo-star/orion.htm).

PNRA - Programma Nazionale di Ricerche in Antartide (http://www.pnra.it).

ROV - Remote Operated Vehicle (http://my.fit.edu/ $\sim$ swood/rov_pg2.html).

R/V - Research Vessel.

SN-1 - Submarine Network-1 (WWW site: http://www.ingv.it/geostar/ sn.htm).

TFH - Techniche FachHochschule (WWW site: http:// www.tfh-berlin.de).

TUB - Technische Universität Berlin (WWW site: http:// www.tu-berlin.de).

VHF - Very High Frequency.

\section{REFERENCES}

Beranzoli, L., A. De Santis, G. Etiope, P. Favali, F. Frugoni, G. Smriglio, F. Gasparoni and A. Marigo (1998): GEOSTAR: a GEophysical and Oceanographic STation for Abyssal Research, Phys. Earth Planet. Int., 108, 175-183.

Beranzoli, L., T. Braun, M. Calcara, D. Calore, R. Campaci, J.-M. Coudeville, A. De Santis, G. Etiope, P. Favali, F. Frugoni, J.-L. Fuda, F. Gamberi, F. Gasparoni, H.W. Gerber, M.P. Marani, J. Marvaldi, C. Millot, P. Palangio, G. Romeo and G. Smriglio (2000a): European seafloor observatory offers new possibilities for deep-sea study, Eos, Trans. Am. Geophys. Un., 81, 45-49.

Beranzoli, L., T. Braun, M. Calcara, A. De Santis, D. Di Mauro, G. Etiope, P. Favali, F. Frugoni, C. Mon- 
tuori, P. Palangio, G. Romeo, G. Smriglio, F. GamBERI, M.P. MARANI, J.-L. FudA and C. MiLlot (2000b): GEOSTAR, an observatory for deep-sea geophysical and oceanographic researches: characteristics, first scientific mission and future activity, Mem. Soc. Geol. It., 55, 491-497.

Beranzoli, L., P. Favali and G. SMriglio (Editors) (2002): Science-technology synergy for research in marine environment: challenges for the XXI century, Developments in Marine Technology Series (Elsevier, Amsterdam), 12, pp. 268.

Beranzoli, L., T. Braun, M. Calcara, P. Casale, A. De Santis, G. D’Anna, D. Di Mauro, G. Etiope, P. Favali, J.-L. Fuda, F. Frugoni, F. Gamberi, M.P. Marani, C. Millot, C. Montuori and G. SMriglio (2003): Mission results from the first GEOSTAR Observatory (Adriatic Sea, 1998), Earth Planets Space, 55, 361-373.

Beranzoli, L., D. Calore, P. Favali, J. Marvaldi and M. NICOT (2004): ORION-GEOSTAR-3: a prototype of seafloor network of observatories for geophysical, oceanographic and environmental monitoring, in Proceedings 14th International Off-shore and Polar Engineering Conference (Toulon, France), vol. II, 371-376.

Berta, M., F. Gasparoni and M. Capobianco (1995): Abyssal Benthic Laboratory (ABEL): a novel approach for long-term investigation at abyssal depths, J. Mar. Syst., 6, 211-225.

Blandin, J., R. Person, J.M. Strout, P. Briole, G. Etiope, M. Masson, S. Smolders, V. Lykousis, G. Ferentinos and J. LEGRAND (2003): ASSEM: a new concept of regional observatory, in Proceedings 3rd International Workshop on Scientific Use of Submarine Cables and Related Technologies, Tokyo, Japan, edited by J. KASAHARA and A.D. CHAVE, IEEE Catalogue No. 03EX660, 240-243.

Calcara, M., L. Beranzoli, T. Braun, D. Calore, A. De Santis, G. Etiope, P. Favali, F. Frugoni, F. GaspaRONI, C. MONTUORI and G. SMRIGLIO (2001): MABEL: a multidisciplinary benthic laboratory for deep-sea, long-term monitoring in the Antarctic, Terra Antarctica, 8, 115-118.

Cenedese, S., M. Calcara, G. D'Anna, K.-U. Evers, P. FAVALI and F. GASPARONI (2004): MABEL: The first seafloor observatory for multidisciplinary long-term monitoring in polar environment, in Proceedings 14th International Off-shore and Polar Engineering Conference, Toulon, France, vol. I, 787-794.

Chave, A.D., R. Butler and T.E. Pyle (Editors) (1990): Proceedings 1st International Workshop on Scientific Uses of Undersea Cables, Honolulu, Hawaii (JOI, Washington DC), pp. 310.

Clauss, G. and S. Hoog (2002): Deep-sea challenges of marine technology and oceanographic engineering, in Science-Technology Synergy for Research in the Marine Environment: Challenges for the XXI Century, edited by L. Beranzoli, P. Favali and G. Smriglio, Developments in Marine Technology Series (Elsevier, Amsterdam), 12, 133-142.

Clauss, G., S. Hoog, F. Stempinski and H.W. Gerber (2004): Advanced deepwater intervention with MODUS - Latest results from model tests and full-scale operations, in Proceedings 14th International Off-shore and Polar Engineering Conference, Toulon, France, vol. II, 377-386.
De Santis, A., D. Di Mauro, L. Cafarella, R. D'Anna, L. Gaya-Pique, P. Palangio, G. Romeo and R. Tozzi (2006): Deep seafloor magnetic observations under GEOSTAR project, Ann. Geophysics, 49 (2/3), 681693 (this volume).

Etiope, G., P. Favali, J.-L. Fuda, F. Italiano, M. Laubenstein, C. Millot and W. Plastino (2006): The Benthic Boundary Layer: geochemical and oceanographic data from the GEOSTAR-2 Observatory, Ann. Geophysics, 49 (2/3), 705-713 (this volume).

Favali, P. and L. Beranzoli (2006): Seafloor observatory science: a review, Ann. Geophysics, 49 (2/3), 515-567 (this volume).

Favali, P., G. Smriglio, L. Beranzoli, T. Braun, M. Calcara, G. D'Anna, A. De Santis, D. Di Mauro, G. Etiope, F. Frugoni, V. Iafolla, S. Monna, C. Montuori, S. Nozzoli, P. Palangio and G. Romeo (2002): Towards a permanent deep-sea observatory: the GEOSTAR European experiment, in Science-Technology Synergy for Research in the Marine Environment: Challenges for the XXI Century, edited by L. Beranzoli, P. FAVAli and G. SMriglio, Developments in Marine Technology Series (Elsevier, Amsterdam), 12, 111-120.

Favali, P., SN-1 TEAm and NEMO Collaboration (2003): SN-1: the first node of the Italian seafloor observatory network - Background and perspective, in Proceedings 3rd International Workshop on Scientific use of Submarine Cables and Related Technologies, Tokyo, Japan, edited by J. Kasahara and A.D. ChaVE, IEEE Catalogue No. 03EX660, 19-24.

Favali, P., L. Beranzoli, M. Calcara, G. D’Anna, G. Etiope, F. Frugoni, N. Lo Bue, G. Marinaro, S. Monna, C. Montuori, T Sgroi, F. Gasparoni, S. Cenedese, F. Furlan, G. Ferentinos, G. Papatheodorou, D. Christodolou, J. Blandin, J. Marvaldi, J.-F. Rolin, G. Clauss, H.W. Gerber, J.-M. Coudeville, M. Nicot, E.R. Flueh, F. Gamberi, M.P. Marani and G. NERI (2004a): Single-frame multiparameter platforms for seafloor geophysical and environmental observations: projects and missions from GEOSTAR to ORION, in Proceedings OCEANS'04, Kobe, Japan, 2000-2007.

Favali, P., L. Beranzoli and A. Maramai (2004b): Review of the Tyrrhenian Sea seismicity: how much is still to be unknown?, in From Seafloor to Deep Mantle: Architecture of the Tyrrhenian Back-arc Basin, edited by M.P. Marani, F. Gamberi and E. Bonatti, Mem. Descr. C. Geol. Ital., LXIV, 57-70.

Gasparoni, F., D. Calore and R. Campaci (2002): From ABEL to GEOSTAR: development of the first European deep-sea scientific observatory, in Science-Technology Synergy for Research in the Marine Environment: Challenges for the XXI Century, edited by L. BERANZOLI, P. Favali and G. Smriglio, Developments in Marine Technology Series (Elsevier, Amsterdam), 12, 143-159.

Gerber, H.W. and G. Clauss (2005): Space shuttle MODUS - Key system for the installation of networks of Benthic stations, in Proceedings OMAE05. 24th International Conference on Off-shore Mechanics and Arctic Engineering, Halkidiki, Greece.

IAfolla, V. and S. Nozzoli (2002): Gravimeter for deepsea measurements, in Science-Technology Synergy for Research in the Marine Environment: Challenges for 
the XXI Century, edited by L. Beranzoli, P. FAVALI and G. SMriglio, Developments in Marine Technology Series (Elsevier, Amsterdam), 12, 183-197.

Iafolla, V., S. Nozzoli, E. Fiorenza and V. Milyukov (2006): Deep-sea gravity measurements: GEOSTAR-2 mission results, Ann. Geophysics, 49 (2/3), 695-704 (this volume).

JourdAIN, J.Y. (1999): First trial of GEOSTAR, the geophysical and oceanographic European station for abyssal research, EC Project Information Booklet EUR18885, edited by G. OlLIER, pp. 31.

Kasahara, J. and A.D. Chave (Co-chairs) (2003): Proceedings 3rd International Workshop on Scientific Use of Submarine Cables and Related Technologies, Tokyo, Japan, edited by J. KaSAHARA and A.D. CHAVE, IEEE Catalogue No. 03EX660, pp. 315.

Marani, M.P., F. Gamberi and E. Bonatti (Editors) (2004): From seafloor to deep mantle: architecture of the Tyrrhenian back-arc basin, Mem. Descr. C. Geol. d'It., LXIV, pp. 195.

Marinaro, G., G. Etiope, F. Gasparoni, D. Calore, S. Cenedese, F. Furlan, M. Masson, P. Favali and J. BLANDIN (2004): GMM-a gas monitoring module for long-term detection of methane leakage from the seafloor, in GEM-Geologic Emissions of Methane from Lands and Seafloor: Mud Volcanoes and Observing Systems, edited by G. ETIOPE and P. FAVALI, Environ. Geol., 46 (8), 1053-1058, doi: 10.1007/s00254-004-1092-2.

Marvaldi, J., Y. Aoustin, G. Ayela, D. Barbot, J. Blandin, J.-M. Coudeville, D. Fellmann, G. LoAËC Ch. Podeur and A. Priou (2002): Design and realisation of communication systems for the GEOSTAR project, in Science-Technology Synergy for Research in the Marine Environment: Challenges for the XXI Century, edited by L. Beranzoli, P. FAvali and G. SMRIGLIO, Developments in Marine Technology Series (Elsevier, Amsterdam), 12, 161-181.

Monna, S., F. Frugoni, C. Montuori, L. Beranzoli and P. FAVALI (2005): High quality seismological recordings from the $\mathrm{SN}-1$ deep seafloor observatory in the Mt. Etna region, Geophys. Res. Lett., 32, L07303 doi:10.1029/ 2004GL021975.

Montagner, J.-P. and Y. LANCElot (Editors) (1995): Proceedings International Workshop Multidisciplinary Observatories on the Deep Seafloor (INSU/CNRS, IFREMER, OSN/USSAC, ODP-France and ODP-Japan, Marseille, France), pp. 229.
NRC (NATIONAL RESEARCH COUNCIL) (2000): Illuminating the Hidden Planet. The future of Seafloor Observatory Science (National Academy Press, Washington DC), pp. 135.

PETERSON, J.R. (1993): Observations and modelling of seismic background noise, US Geol. Surv. Open File Rep. 93-322, pp. 94.

Priede, I.G., M. Solan, J. Mienert, R. Person, T.C.E. van Weering, O. Pfannkuche, N. O'Neill, A. Tselepides, L. Thomsen, P. Favali, F. Gasparoni, N. Zitellini, C. Millot, H.W. Gerber, J.M.A. De Miranda and M. KLAGES (2003): ESONET - European Seafloor Observatory NETwork, in Proceedings 3rd International Workshop on Scientific Use of Submarine Cables and Related Technologies, Tokyo, Japan, edited by J. KASAHARA and A.D. Chave, IEEE Catalogue No. 03EX660, 263-265.

Priede, I.G., P. Favali, M. Solan, F. Gasparoni, J. Mienert, N. Zitellini, R. Person, C. Millot, T.C.E. van WeEring, H.W. Gerber, O. Pfannkuche, J.M.A. de Miranda, N. O’Neill, M. Klages, A. Tselepides, P. Sigray and L. Thomsen (2004): ESONET - European Seafloor Observatory NETwork, in Proceedings OCEANS'04 MTS/IEEE TECHNO-OCEAN'04, Kobe, Japan, IEEE Catalogue No. 04CH37600C, 2155-2163.

Rigaud, V., D. Semac, M. Nokin, DESIBEL Team, G. TIetze, H. Amann, V. Goetz and A. Pascoal (1998): New methods for DEep-Sea Intervention on future BEnthic Laboratories, DESIBEL project - Final results, comparison of concepts and at sea validation, in Proceedings of the IEEE Conference OCEANS '98, Nice, France (on CD-ROM).

Romanowicz, B., K. Suyehiro and H. KawaKatsu (Editors) (2001): OHP/ION joint symposium long-term observations in the oceans. Current status and perspectives for the future, Workshop Rep., Yamanashi Pref., Japan, pp. 188.

Utada, H., K. Noguchi, C. Harayama and N. Natsushima (Editors) (1997): Proceedings International Workshop on Scientific Use of Submarine Cables, Okinawa, Japan, pp. 234.

Thiel, H., K.O. Kirstein, C. Luth, U. Luth, G. Luther, L.A. Meyer-ReIL, O. PfannKuChe and M. Weydert (1994): Scientific requirements for an abyssal benthic laboratory, J. Mar. Sys., 4, 421-439.

WEBB, S.C. (1998): Broad-band seismology and noise under the ocean, Rev. Geophys., 36 (1), 105-142. 